\title{
一般演題抄録
}

\section{基 礎}

座長 自治医科大学整形・リハセンター 大井 淑雄

II-B-1 $\sim 4$

\section{II-B-1．廃用萎縮に関する基礎的研究}

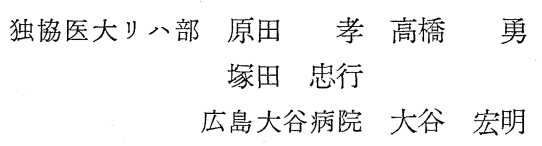

リハビリテーション医学にとって, 廃用萎縮や変形 は，極めて重要な課題で，我々は，こうした点に関する 基礎的な研究をすすめているが，今回は，二，三の脱水 素酵素を調ベ，アルカリホスファターゼ (AL-p) と, ライソゾーム系酵素である酸ホスファターゼ $(\mathrm{AC}-\mathrm{p})$ とを対比し，検討してみた．2～3 kg の家鬼の膝関節を 使用した。不動の条件を作るために，右膝関節中心に大 腿から足尖までギプス固定し，2 週後，4 週後，6 週後 と経時的に関節軟骨を採取して，左膝関節を 対照とし た。合計 40 関節について調査した。検索した酵素は,

（1） AC-p, (2 ）AL-p, (3 ) M.D.H.（リンゴ酸脱水 素酵素)，（4）L.D.H. (乳酸脱水素酵素) である. 酸 ホスファターゼは，軟骨の全層にほぼ均等に認められ， 基底層にやや強いが，ギプス固定後 2 週では，軟骨の表 層でやや低下してくることがわかった．これは，HE 染 色による組織像の変化に先行するものである. ライソゾ 一ム系酵素の一つであるこの酸ホスファターゼは, いわ ば, 細胞内の消化酵素としての役割が重要視され, 細胞

1) An Experimental Study of Disuse Atrophy. T. Harada, I. Takahashi, T. Tsukada : Rehabilitation Medicine, Dokkyo Univ. School of Med.

H. Ohtani : Hiroshima, Ohtani Hospital.
内外の変化に対して homeostasis を司どることを一つ の働きとしているので, ギプス固定 2 週後にみられる酸 ホスファターゼ活性の低下は, 関節内の代謝に一つの異 常をきたしてきた現われと考光られる。

AL-p は，主として基底層に認められ，M.D.H. と L.D.H. は，共に軟骨のほぼ全層に均一に証されるが， ギプス固定 4 週後では, $\mathrm{AL}-\mathrm{p}$ も両脱水素酵素も共に活 性が低下してくる。しかし酸ホスファターゼの低下ほど 著しくはない。ギプス固定 6 週後では, 細胞核や胞体の 染色性の低下, 軟骨細胞の配列の乱れ等の組織像の変化 が更に進行し， $\mathrm{AC}-\mathrm{p}$ も $\mathrm{AL}-\mathrm{p}$ も著しく低下するが， ミトコンドリアに配属される脱水素酵素は, 前二者に比 してその影響はやや少ない，以上述べてきた如く，関節 の固定という不動の条件は, 関節軟骨の代謝に極めて重 大な影響を与えていることが酵素活性の面からも裏付け 出来たものと思う.

\section{II-B-2．膝関節疾患における大腿四頭筋訓練 の Cybex 的評価}

自治医科大整形・リハセンター
井上 和彦 大井 淑雄 須賀 哲夫
御巫 清允 谷岡 淳
東京女子医大第二病院 菅原 幸子
石上 宮子 松木 孝行

膝関節疾患において大腿四頭筋訓練は保存的治療の中 心である.しかし，従来は筋力測定の適当な機器がない ために，大腿四頭筋訓練の重要性は認識出来たが，その 評価は十分とは言えなかった。 Cybex Machine は動的

2) Evaluation by Cybex Machine for Quadriceps Training in Knee Disorders.

K. Inoue, Y. Ooi, T. Suga, K. Mikanagi, J. Tanioka : Dept. of Orthopaedic Surgery and Rehabilitation Center, Jichi Med. College. S. Sugawara, M. Ishigami, T. Matsuki : The 2nd Branch Hospital, Tokyo Womens' Med. College. 
状態で, 容易に粗大筋力測定が可能なため大腿四頭筋力 の再評価を行った。症例は, 慢性関節リウマチ, 変形性 膝関節症，半月損傷各 15 関節，計 45 関節であった。

<方法＞坐位をとり，足部をサイベックスのアームに 固定し，できるだけ早く㯟の屈伸を繰返した。測定前に 測定の必要性, 機器の特徴, そして測定の要領について 患者に話すのは非常に重要である.今回は最大トルクの みについて検討を加えた。慢性関節リウマチでは, 訓練 によりトルクの軽度の増加をみたが, 関節痛や熱感腫脹 によりトルクは減少した。しかし, 訓練により伸筋と屈 筋の比は改善し，バランスのとれた筋力関係になってい た。

変形性膝関節症では, 伸筋トルクの著明に減少した例 が多く認められたが, 屈筋の減少は軽度であった。 中に は伸筋トルクの低下が著しく, 屈筋が伸筋より大きい逆 転現象もみられた。関節軟骨の軟化摩耗そして大腿滕蓋 関節への障害を考えると当然であるう。訓練効果は, 訓 練効果のほとんど認められない例と, 著明に認められる 例とあり，ほぼ 4 週間で分かれた。半月損傷例では, 伸 筋力の低下は, OA 例に比較して軽度であり, 屈筋力 の低下はほとんぞなかった．訓練効果は屈伸筋ともに著 明であったが，中には 1 週間程でプラトーに達する例も ありこのような例には、いたずらに訓練を続けること なく他の方法を選択すべきである。

他に, 半月切除等の手術後に, い頃から通常の生活 にもどったらよいか等の判断に筋トルクの面からのアプ ローチも可能であり, 半月損傷では術後約 10 週間で筋 力のかなりの回復がみられ，この頃が通常生活への復帰 時期であろら.

\section{II-B-3. Cybex Machine II による TVR 効果の臨床評価について}

千葉大学理学療法部 中川 武夫 北原宏
千葉大学整形外科 小林 英夫 井上 駿一
千葉大学神経内科 渡辺 誠介

振動刺激は近年生理学で筋紡鍾を興奮させる作用が注

3) Studies of Tonic Vibration Reflex by Cybex Machine II.

T. Nakagawa, H. Kitahara: Division of Physical Therapy, School of Medicine, Chiba University.

H. Kobayashi, S. Inoue : Dept. of Orthopaedic Surgery, School of Medicine, Chiba University.

S. Watanabe : Dept. of Neurology, School of Medicine, Chiba University.
目されているが，この作用の現われを Tonic Vibration Reflex 之呼ぶ. 我々はこの立場より振動刺激の Isokinetic な運動におよぼす影響を Cybex Machine II を 用いて検討したので報告する.

く方法〉運動速度は 5 RPM を使用し, 運動方法を理 解させた後に測定を行った。運動は始め振動刺激をせず に行い，次にVibrator を大腿四頭笳腱上に固定し刺激 開始 30 秒後より運動を開始した.Vibrator は平和電子 製 Hagbarth Type Model HV-BD を使用し，刺激は $100 \mathrm{~Hz}$ を用いた。

<対象>正常人は平均年齢 26 歳男子 16 名を刘象とし た．片麻痻患者は 21 例でその患側を対象とした。性別 は男 15 例，女 6 例，平均年齢は 54 歳 10 力月，発症後 経過年数は平均 2 年 10 力月, 患側は右 17 例, 左 4 例で あり，Brunnstrom Stage は 6 が 6 例， 5 が 3 例， 4 が 6 例, 3 が 6 例, となっている.

く結果〉正常人の最大トルク平均值は Quadriceps で は control で $88.9 \pm 7.5 \mathrm{ft}-\mathrm{lbs}$, 振動刺激下では $97.9 \pm$ $8.6 \mathrm{ft}-1 \mathrm{bs}$ であり, Hamstrings では control で $63.8 \pm$ $8.1 \mathrm{ft}-1 \mathrm{bs}$, 振動刺激下では $61.0 \pm 8.2 \mathrm{ft}-1 \mathrm{bs}$ であっ た。振動刺激の Quadriceps への促通は平均 9.1 $1 \pm 5.4$ $\mathrm{ft}$-lbs の有意なトルク増加となっており, 最大トルク発 揮時間も Quadriceps で平均 $0.08 \pm 0.05$ 秒, Hamstring で平均 $0.12 \pm 0.10$ 秒と有意な短縮を認めた。片麻 㾇群では最大トルク平均值は Quadriceps では control で $27.5 \pm 10.4 \mathrm{ft}-1 \mathrm{bs}$ ，振動刺激下で $30.8 \pm 10.7 \mathrm{ft}-1 \mathrm{bs}$, Hamstrings では control で $13.8 \pm 5.4 \mathrm{ft}-1 \mathrm{bs}$, 振動刺 激下で $12.4 \pm 5.9 \mathrm{ft}-1 \mathrm{bs}$ であ施た。振動刺激の Quadriceps は $3.7 \pm 2.7 \mathrm{ft}-1 \mathrm{bs}$ の有意なトルク増加となって おう，最大トルク発揮時間も Quadriceps で $0.5 \pm 0.14$ 秒, Hamstrings で $0.10 \pm 0.09$ 秒と有意に短縮してい た。

くをとめ>Hagbarth は振動刺激を Isometric な状態 で観察し, 刺激筋への促通, 拮抗筋への抑制効果を述べ たが，我々はIsokinetic な状態でも同様な現象が起こ ることを観察し得た。最大トルク発揮時間短縮について 更に検討を要する.

\section{II-B-4．遠心性収縮を応用した筋力強化訓練 と他の訓練方法との比較}

\author{
川崎医科大学りハビリテーション科 \\ 長尾 史博 明石謙土肥信介 \\ 長谷川寿美玲 日野 洋介
}

遠心性収縮とその他の 訓練方法の 比較は，1967 年明 石，1968 年 Doss らが，遠心性収縮が訓練効果が大き 
いと報告している. 今回我々は正常人 30 人の小指外転 筋を使用し, 遠心性収縮とその他の訓練方法を比較検討 した。

30 人を 10 人ずつ 3 群にわけ, A 群 Delorme-Watkins 法, B 群は等尺性運動で最大収縮 6 秒間, 1 日 5 回訓練を行った。 C 群は，遠心性收縮で最大筋力に $500 \mathrm{~g}$ の重量を加兄, 筋肉を充分収縮させた後負荷を加 え，1日 5 回訓練を行った。・ヒズミ計を使用して，筋 力, 関節角度の変位量の両方が測定できる測定器を作製 した， $\mathrm{Y}$ 軸方向に筋力， $\mathrm{X}$ 軸方向に関節角度をとり， $\mathrm{X}-\mathrm{Y}$ レコーダに 記録させ， 10 回の最大筋力，平均筋 力, 仕事量, 仕事率を測定し, 同時に表面電極を用いて 積分值を記録した。 また非訓練側の筋力について, 初回 訓練前と最終訓練後に測定し, Cross-Education につい ても調べた。平均筋力の増強は， $\mathrm{A}$ 群 $216 \% ， \mathrm{~B}$ 群 195\%，C 群 172\% であり，A 群と C 群において有意 差を認めたが，仕事量，仕事率で差はみられなかった。 Doss，明石らの結果と反対になった理由として，負荷 量, 回数, 笳肉による差と思われる. 訓練後 1 週目の測 定で, 仕事量が 30 人中 9 人 (A 群 3 人, B 群 4 人, C 群 2 人) において低下した理由として，日常使用される ことの少ない小指外転筋のため，疲労，筋痛によるもの と考㝋られる.角度と最大筋力の関係であるが，A群， $\mathrm{C}$ 群は, 最大筋力が $40^{\circ} \sim 50^{\circ}$ に対して, B 群では, $0^{\circ} \sim 20^{\circ}$ で最大筋力が得られた，表面電極を用いて積分 值は, 平均筋力, 仕事量, 仕事率との相関はみられなか った。 Cross-Education については, 平均筋力で A 群 $+48.2 \%, \mathrm{~B}$ 群 $+23.6 \%$, C 群 $+31.9 \%$ の増加をる, 動的訓練法（A，C群）に有意差を認め, 仕事量, 仕事 率共に同じ結果を得た。

<質問 >独協医大り八科 高橋 勇: (1) 小指外転 筋での実験成績が他の諸筋についても当てはまるかどう か。一般に握力は廃用萎縮を起こす傾向が少ないといわ れているが，こんな点から考えても，筋の種類によって 若干様子が違うのではないかと思う。(2)このことは運 動単位の点からも言光ることで, 手指筋では phasic motor units が多いが， tonic motor units の多い下肢 筋とは自ずと筋力の増強の様子が異なるものと考兄る が，いかがですか。

<答>明石 謙 : (1) 小指外転筋を選んだ理由は訓 練効果が, isolate しやすいことと, cross education の

4) Comparative Studies of Eccentric Contraction Exercise and Other Muscle Strengthing Exercise.

F. Nagao, N. Dohi, Y. Hino, S. Hasegawa, K. Akashi : Department of Rehabilitation, Kawasaki Medical School.
効果をしらべやすい点からで，おっしゃる通り他の筋の 筋力強化に京で同じ考光を広めることは問題があるかも 知れません. (2) 仕事率は各訓練法に差がないので小指 外転筋が主に phasic fibre で構成されているといら説 を裏づけているように思います。

\section{脳性麻痺}

座長 埼玉県生活福祉部障害福祉センター

五味 重春

ひかり整肢学園 寺沢 幸一

\section{II-B-5 18}

\section{II-B-5，脳性麻痺の早期診断治療に関する地 域保健事業的研究 (1)}

愛知県心身障害者コロ $=-$ 福嶋 正和 愛知県知多保健所 伊藤 桂子

脳性麻疩 (CP) の早期診断治療は 地域保健事業への 統合が不可欠である.

<目的と方法>我々は過去 3 年余にわたり保健所 3 力 月健診を中心に CP 危険児について早期診断を行い, 治療例では治療を継続すると共に, 地域保健婦の家庭訪 問による治療の助言と徹底化を要請した。診断にはミュ ンヘン機能的発達診断法, ボイタ早期診断法を中心とし たミュンヘン式発達神経学的検査が，治療には主として ボバース法が行われた。

<結果>1 ）早期診断初診時の月齢：1975 年 5 月一 1978 年 12 月で CP の疑いで保健所などから紹介され た症例数は 101 例である. そのらち生後 1 年までの早期 初診例は 95 例 $(94.1 \%)$ であり，とくに $3 \sim 7$ 力月初 診例が大半を占めた.

2) CP 巟の治療開始時期：治療総数は 32 例であり, そのらち早期治療例は 24 例 (75\%) であった。

3) ボイタ早期䛦断法に上る異常反応数と早期治療： 4 個以上の 異常反応数を示したのは 43 例でそのらち治 療例は 27 例であった。治療適応はボイタ法だけでなく

5) Communal and Health-Preservative Study on the Early Diagnosis and Treatment of Cerebral Palsy (1).

M. Fukushima : Aichi Prefecture Colony for the Handicapped.

K. Itoh : Sanitary Board Chita, Aichi Prefecture. 
発達神経学的検查を総括して決定した。

4) CP 児の早期治療の効果：1978 年 8 月までに初 診し， 5 力月以上治療継続された例は 28 例でそのうち 著明な効果 6 例，かなりの効果 8 例，やや効果 9 例拉よ び効果なし 5 例であった。

5 ) 早期診断児の歩行月齢之 1979 年 2 月現在の言語 発達: 歩行月齢は $11 \sim 26$ 力月に分布するが，18 力月京 での歩行例が $76.92 \%$ を占めた。言語では良好 30 例 (54.5\%), やや遅滞 14 例 (25.5\%), 打よび著明遅滞 (20.0\%) であった。早期歩行例では言語発達良好であ ったが，その他では両方に相関関係なし。

く考察>CP は種々の障害を伴っており, 重複障害と

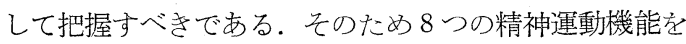
評価できるミュンヘン機能的発達診断法は $\mathrm{CP}$ 評価に 有意義である.

\section{II-B-6. 脳性麻痺の早期診断治療に関する地 域保健事業的研究 (2) 一アンケ 一ト調査を中心に}

\author{
愛知県心身障害者コロ $=$ - 福嶋 正和 \\ 愛知県知多保健所 伊藤 桂子 \\ 名古屋市中川保健所 且井 利夫
}

$\mathrm{CP}$ の早期診断治療を地域保健婦事業的に実践する基 礎資料とするため, 保健所 3 力月乳児健診で母親の $\mathrm{CP}$ に対する意識および子どもへの把え方について調查する ことは意義あることと思われる．

我々は知多保健所 3 力月乳児健診時(昭和 53 年 2 月 1 日〜 3 月 17 日）打よび中川保健所 4 力月健診時（同 53 年 3 月 1 日〜 5 月 17 日) でアンケート調査を実施し, 前所で 519 名, 後所で 405 名の協力が得られた. アンケ 一ト項目は 17 項目（第16回日本りハビリテーション医 学会総会プログラム・抄録集に記載）にわたるが， 1）～4）は母親の意識について，5）～9）は主とし て既往歷について，ならびに 10）～17）は子どもの現 症についての質問である。

＜結果＞1）母親の意識：大ていの母親は $\mathrm{CP}$ とい ら言葉を知っている（約 $95 \%$ ）が, 正確な知識をるって

6) Communal and Health-Preservative Study on the Early Diagnosis and Treatment of Cerebral Palsy (2).

M. Fukushima : Aichi Prefectural Colony for the Handicapped.

K. Itoh : Sanitary Board Chita, Aichi Prefecture.

T. Usui : Sanitary of Nakagawa, Nagoya City.
いるのは $10 \%$ に満たない。その一方で，CP が遺伀 しないとしたのが， $60 \%$ 強を示したことが注目される。

2 ) 子ぞもの既往歴：異常之正常の識別を母親の判断 にゆだねることは困難であるため，参考データにとどめ ておく.

3）子ぞもの現症：8項目にわたって危険因子の有無 を総症例数 924 名について調查した：危険因子数 0 の の 560 名 $(60.6 \%), 1$ 個のもの 290 名 $(31.4 \%), 2$ 個 のもの 64 名 $(6.9 \%), 3$ 個のもの 9 名 $(1.0 \%)$ ならび に 4 個のもの1名 $(0.1 \%)$ であった。

<考察〉以上の結果より，危険因子数の多いもの注ぞ CP の可能性があることは想定されるが，CP そのもの であることとは別問題である. しかし危険因子数 3 個以 上のものは CP 危険児として精查する必要はあ⿱丶万。

今後はアンケートの項目および分析法について標準化 し, CP 危険児の選別の客観的規準を作るべきである.

\section{II-B-7. 保健所活動から見た脳性麻㾇の早期 発見・治療}

$\begin{array}{llll} & \text { 東京都立北潦育園 } & \text { 中島雅之輔 } \\ \text { 高橋 } & \text { 純 甘楽 } & \text { 重信 } & \text { 藤本輝世子 } \\ \text { 山崎 ユキ 川上 } & \text { 義 } & \text { 山本 恵子 }\end{array}$

$<$ 目的>我々は昭和 51 年 4 月より，東京都練馬区内 の保健所と協力して, 脳損傷児の早期発見・療育に努め て来た．今回はそのシステムを更に拡大化・徹底化させ たので，その結果を報告する。

<方法>人口約 56 万人の練馬区において，昭和 51 年 10 月 1 日から同 53 年 3 月 31 日字での 1 年半に出生し た 11,826 人を乳児健診により前回発表の既往歷，所見 を基にしてスクリーニングにかけた。乳児健診に漏水た 児童には電話・文書等で来所を勧め，更に未来所児には 発達段階をみるためのアンケート調査を行い，異常のあ る症例は来所を歓めた。

<結果 >死亡・転居を除く之全対象児は 10,503 人 で，把握可能児は 10,480 人，不明児 23 人で把握率は 99.8\%に達した，把握された児童中，精査要となった児 童は 313 人であった。精查により, 正常 74 例，軽度発達 遅滞で数カ月後に診察要 79 例, 著しい発達遅滞のため 保健所内で訓練・指導要 87 例, 発達遅滞に加光発達異

7) Some Results of Early Detection and Treatment of Cerebral Palsy in Public Health Centres.

M. Nakashima, J. Takahashi, T. Tsuzura, T. Fujimoto, Y. Yamazaki, Y. Kawakami, K. Yamamoto: Tokyo Metropolitan KitaRyoikuen Hospital for Cerebral Palsy. 
常があり療育施設に紹介 49 例であった。暫定的診断は， 脳性麻痺 8 例, 精神・運動発達遅滞 154 例, 症候性危険 児 37 例，正常 90 例であった．乳児健診を通さずに直接 療育施設を訪れた児童を加えると広義の脳性麻瘏は 11 例で，そのらち重症心身障害 5 例，狭義の脳性麻疩 6 例 であった。広義の脳性麻痺の発生率は 1 万人出生に対し 約 10 人であり，危険児は $40 \sim 50$ 人であった。

<考察>脳性麻瘦の発生率は $0.15 \sim 0.2 \%$ といわれて いるが, 今回の我々の調查では極めて低く, 今後肢体不自 由児施設のあり方に大きな影響を与えると考えられた。 脳損傷等, 新生児期に重篤な症状のあった児童は, 保健所 健診に訪礼ないことが多いので，特別な対策が必要であ る. 乳児健診の質向上のため, 乳児健診担当医, 保健婦の 障害児発見に関する教育を療育施設は担うべきである。

<質問 >石川整肢学園 过 成人 $(I-B-5 \cdot 6 \cdot 7$ V 対して)：単に, CNS の危険児に関して早期発見に努 カするだけではなく, 眼や聴力についての障害発見に対 する努力は，どらして和られますか。また眼科医や耳鼻 科医の協力状態については如何。

<答 $>$ 福嶋 正和：CP の早期診断に和ける視覚拈よ び聴覚の検查について：視覚については保育器使用・酸 素供給例についてはとくに未熟児網膜症のチェックを行 っている.またその後の視覚および聴覚の発達のチェッ クは, ミュンヘン機能的発達診断法 (Münchener Funktionelle Entwicklungsdiagnostik) の知覚年齢表に 基ついて行っている. そして必要に応じて，眼科医拉よ び聴覚検査士を受診するよう指示している.

<答>中島雅之輔 : 視覚・聴覚の検査は必須でありま して，障害が疑われる症例は専門家の指示をあおいでお ります。

<質問 >東京女子医大リハビリ 山形 恵子 : 早期診 断で, 病院や診療所で発達上に疑問を持った際（risk baby を疑った時)，東京では施設関係で充分受け入れて 早期治療悉たは生活指導を和願い出来末すでしょらか。

<答>中島雅之輔 : 現在でも危険児が送られて来ます が，危際児を受け身で，受け入れるといらょりは，積極 的に教育することが必要と考光ます。

<追加 > 神戸大学整形外科 坂田 政泰: 早期発見の 重要なことはとくと承知の上で申し上げる.“赤ちゃん” の発育には幅があり, 神経学的発達と運動発達との間に 差がある場合に，正常か否かの診断をすることは甚だ困 難である.

現場に执いて，いたずらに“パニック・メーカー”之 ならないための診断の根拠となる指標はないものだろら か？ 異常であることを告げる以上に，正常であること を告げて親を安心させることが大切だと考えている。
＜質問＞高知県立子鹿園 江口寿栄夫 : 春髄損傷例之 分かった症例はなかったか $\left(\mathrm{C}_{1-2}\right.$ の脱臼で四肢瘦麻を 来している症例を経験しているので).

\section{II-B-8. 岡谷保健所における 3 年間の脳障害 児早期発見クリニックの結果につい $\tau$}

（演題中止）

\section{II-B-9．脳性麻瘴超早期治療の経験}

\section{長崎大学整形外科 䅖山富太郎 岡本 義久 陳 㲊恒 鈴木 良平 長崎県立整肢寮育園 川口 幸義}

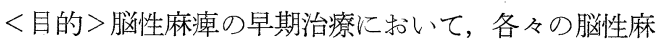
痺児の到達目標は, 理想的な治療下において到達されら る最高点に抢かれることが大切である。 その目標到達に は，治療テクニックもさることながら新生児期から開始 するという時期的要素もまた重要である．かかる観点か ら我々は生後 3 力月未満からの超早期治療を試及た。

$<$ 対象之方法>脳性麻痺の早期診断は生後 3 力月未満 に抏いて困難とされているが，新生児期からの診断も可 能である. 対象は過去 3 年間に当科外来を受診した high risk 児のうち, 初診が新生児期から生後 2 力月の 間にあり，かつその期間に要治療と判断し，治療を施し た 32 例であった。結果的に 16 例が脳性麻晫となり, 診 断の的中率は $50 \%$ であった. 治療は Bobath の方法に ならった. Bobath の治療概念に执いて, (1) 評価と治療 は別々のものではない, (2) 発達初期に 必要な感覚経験 を与光ること, (3) 母子関係の正常な 発達一一感覚刺激 による乳児から母親への attachment と母親から乳児 への attachment からなる—などが強調される。概 して, 発達初期においてこ扎ら感覚刺激, 感覚経験は不 足しがちである.我々は，特に生後最初の 3 力月間にお いて，(1) 原始反射を利用した正常感覚運動機能の獲得， (2) 情緒的 attachment に上る行動発達の促進, (3) 関節 周囲に存在する小体性 Mecanoreceptor は出生後の機 械的ストレスによって機能的成熟が促されるが，側卧 位, 腹臥位獲得に関連した head righting, 伸展緊張 の発達促進などに留意して治療を施した。

9) Very Early Treatment of Cerebral Palsy. T. Akiyama, Y. Okamoto, Y. Chen, R. Suzuki : Department of Orthopedic Surgery, Nagasaki University School of Medicine. Y. Kawaguchi : Nagasaki Crippled Children's Hospital. 
く結果〉発達障害が予測された 32 例の high risk 肾 のらち，16 例は脑性麻舫となり 1 例は知的発達障害で あった。脳性麻㽻 16 例中 3 例は歴年齢々一致した発達 年齢を示した。未治療の場合との比較は不可能だが，従 来の軽症児は正常児近くまで，中等症は軽症まで，重症 は中等症まで発達促進されたと推測した。

<質問>北九州市総合療育七ンター 高松 鶴吉 : 先 生は御演題の中で Brazelton の評価法について御説明 をされました。この評価法は大変時間がかかると思いま すが，実際の臨床場面で実施されているのですか.

<答＞䅖山富太郎：テクニックの修得のために専用の 検查室を設け，27 項にわたる検查を行ってきたが，多 くの時間を要するので, 通常の外来診療では, 適当な数 項目を選んで従来の検查に追加して行い，有用である.

<質問>愛知県心身障害者コロニ一篠田 達明 : 生 後まもない新生览にも“くびのすわり”があるとのこと ですが，“くびのすわり”のまったくみられない重症心 身障害児においても腹臥位をとらせると，ごくわずかに くびをもちあげることから，新生児のそれも，らつぶせ の姿勢での Nacken-Muskel の収縮による一現象と推 測され，“くびのすわり”とは異なるよらに思われます が，先生の御見解はいかがでしょらか.

<答＞䅖山富太郎：正常览の新生児期に括いて head up, head control は誘発されらる程度までに発達して いることは事実である. 重度脳障害児にみられる head up は異常姿勢緊張に基づいているこが多いとはいえ， その中にも, head righting reaction が多少ともふくま れている可能性があり，それを見抜くことが評価に際し て重要である.

\section{II-B-10. 眼性麻痺重度化の 因子に関する研 究——早期治療例の訓練効果と CT 所見}

国立療養所南九州病院 帛中 裕幸

心身障害の発生予防や脳性麻瘨の重度化防止のため, 脑性麻瘦を中心とした脳障害児の早期発見, 早期治療に とりくんで 2 年が経過した. 早期発見には診断学上の困 難がつきまとい，訓練効果にはばらつきが見られる。こ こに CT 所見が，補助診断や，予後の判定に有用では ないかと考え 120 名の CP に CT を施行した。120名 のらちわけは spastic type が90名 (Quadriplegia 55 名, Triplegia 1名, Hemiplegia 23 名, Diplegia 9 名, Monoplegia 2 名), Athetoid type 17 名, Mixed type 8 名, Atonic type 8 名であった. 異常所見は Quadriplegia で81.8\%に, Hemiplegia で82.6\%に
異常を認めた。Athetoid type は23.5\%に，Diplegia では $11.1 \%$ にしか異常所見を認めなかった。 また異常 所見の内容も Quadriplegia に高度かつ多彩な所見を認 め, Athetoid type には軽度のものが多かった. Mixed type は両者の中間の所見を呈した。

早期治療例では経過良好群が 13 名あり， 7 名は正常 所見， 1 名に中等度の所見を見た以外は 5 名は軽度の異 常所見であった。一方早期治療例の 経過不良群 9 名に は，高度の 異常所見を呈する者が多かったが，1名は CT 所見は完全に正常之思われるにもかかわらず，生後 4 カ月より訓練をつづけ，現在 2 歳になったがまだ首采 わりを見ない．現在の CT では，臨床症状に対応して， 脳損傷の 程度や部位を的確にとら兄るとは考兄にくい が，早期診断や，予後の判定に有用であると結論した。 また早期治療に上り, ある程度重度化の予防にも成功し ているとの印象を強めた。

<答〉香中 裕幸（長崎大小児科の先生に対して）： 周産期異常と CT 所見のむすびつきについてはまだ結 論を出して括り末せん，早期治療例は 1 例をの年き，全 例に周産期異常を認めて求ります。1 例は乳児院よりの 紹介で，周産期異常は不明です。

\section{II-B-11. 各種発達障害児の CT}

安曇病院整形外科 杉浦 憲治 深瀬 継允 信州大学整形外科 藤本 憲司

我々は最近の 8 カ月間に, 発達診断のため当科へ紹介 されてきた 28 例に，診断補助および，予後判定のため CT scanning を施行してきた.

症例は生後 1 力月より 4 歳までで平均 16 力月. 臨床 診断名及び数は, CP 14 例, microcephalus 6 例, 点頭 テンカン 5 例, 脳腫瘍, 急性脳炎, 急性小児片麻軒, Lipidosis 各 1 例で，次のごとき結果を得た。 Spastic quadriplegia では皮質萎縮が著明でいわゆる硬膜下水 腫の状態を多く示し, 脳室拡大も全例に認めた. Spastic diplegia では脳室拡大の程度と臨床的重症度がよく

10) A Clinical Approach to Aggravative Factors of Cerebral Palsy-Relationship of Very Early Treatment Cases and its CT Scan Findings. H.Hatanaka : Minami Kyushu National Hospital.

11) CT of Various Disabled Children.

K. Sugiura, T. Fukase : Azumi Hospital Orthopedic Surgery.

K. Fujimoto: Department of Orthopedic Surgery, Faculty of Medicine, Shinshu University. 
相関したが，皮質萎縮はあっても軽度であった。infantile spasms で運動障害のないものでは異常を認めなか った. acute encephalitis 拈よび acute hemiplegia in childhood では，急速な CT 像の改善と並行して臨床 的に改善をみた. spastic hemiplegia では brain tumor との 臨床的鑑別は困難であるので，CT を必ず 施行すべきであると考える。

<質問>愛知県 コロ $=-$ 福嶋 正和 (II-B-10, 11 に対して）：CT 所見で重度の脳発育不全のみられた 症例に护ける早期治療の適応は如何か？

<答＞皇中 裕幸：どんな重度の脳障害児でも, 重度 化の予防たとえば関節拘縮や変形，脱臼なぞを防ぐとい う意味と，診断を下した以上は，親を安心させる意味で リハビリは続ける必要があると考えております。

<答>深瀬 継允：CT はあくまで morphological な観点のみを観たのみであり， neuro-biochemistry の 問題も無視できない。ぞんな重度な子供であっても大き な function を期待しさえしなければ，治療の対象とな ると考える，また，変形拘縮の予防を努める意義はある と考える.

<質問 $>$ 神戸大学整形外科 坂田 政泰：CP の頭蓋 骨の変形，または脳実質や脳室の占める幾何学的関係と 臨床像との相関について抒教え頂きたい。

<答>杉浦 憲治：hemiplegia では反対側の変化が 明らか. diplegia では cistern の拡大と重症度がよく相 関した。

<答 > 杉浦 憲治(周産期障害のないものの CT につ いての質問に対して）：症例に 周産期障害のないものが ない。

\section{II-B-12. 重度・重複障害児に対する医学的 リハビリテーションー一訪問指導 学級在籍児童の実態調査より}

横浜市立大学リハビリテーション科 佐鹿 博信 大川 嗣雄 伊藤 利之

神奈川県立こぞも医療センター 陣内 一保 神奈川リハビリテーションセンター 安藤 徳彦 横浜市立大学小児科 三宅 捷太

学齢期の在宅の重度・重複障害児に対して, 医学的リ ハビリテーションの立場から如何に対応するかは大きな 課題である.こらいった児童に対して,横浜市では訪問指 導学級といら形態で家庭訪問による教育が実施されてい る.我々は, 1977 年 10 月に教育委員会の協力を得て, 訪 問指導学級在籍児童の実態調査を行い，医学的リハビリ テーションからの対応について検討したのて報告した。
対象児は 128 名であったが，調查を行うことのできた ものは 96 名であった，平均年龄は 11.8 歳であった。運 動障害の評価のために神経生理学的・発達診断学的価值 を，知的機能の評価のために遠城寺などの乳児精神発達 検查を用い，さらら，専門医の協力を得て随伴・合併障 害を評価した。

主病名では，脳性麻痺が最も多く 34 名，35\%を占 め，ほとんぞ中枢神経系の障害であった，精神発達遅滞 を伴うものが $92 \%$ を占め, 発達指数が 20 末満で意思疎 通不能のものは $59 \%$ であった。坐位保持不能のものは 34\%であった，従って，いわ沛る重症心身障害児は 43 名，45\%であった，単一障害児は 30 名，31\% であり， このらち精神発達遅滞児は 22 名であった．ADL が自 立しているものは10名であった。 $90 \%$ の児童が何らか の合併障害を有し，高度の拘縮・側彎症や，てんかん発 作・奇異呼吸・低体重なぞが重大な合併障害であった。

これらの重度・重複障害児に対して，われわれは障害 の評価に基づき，発達歴と follow up により，発達が 見込まれるもの・発達の可能性の乏しいもの・退行が見 込まれるもの，の 3 群に分類して対応していった．今後 も，在宅といら特殊な条件を考慮した評価法の検討を進 め，障害の分類と適切な対応をより明確にしていく必要 がある．在宅の重度・重複障害児の医学的リハビリテー ションは，人材・設備の面で大きな制約があり，効果は 多くを期待できないが，今後も教育少イドに対して指 導・援助をしていく必要があると考㝋られた。

<質問 $>$ 神戸大学整形外科 坂田 政泰：訪問教育制 度といえば, 神奈川方式とか, 兵庫方式とか言われまずが， 現実にメディカル・ケアはどのようにされていますか。 当方では，神戸では年 4 回のチェックが可能ですが，そ れ以外では野放しの状態に近いのが現状です。

<答 $>$ 佐藤 博信 : 横浜市内の学龄期在宅重度 - 重複 障害児に対する医療のシステムは，主として，県立こど も医療センターの外来にて管理されています。また，

12) Medical Rehabilitation for the Severely Handicapped Children : A Study of Children Having the Compulsory Educational Programs by Visiting Instructor.

H. Sashika, T. Ohkawa, I. Itoh : Department of Rehabilitation Medicine, Yokohama City University School of Medicine.

K. Jin-nai : Kanagawa Children's Medical Center.

N. Ando: Kanagawa Rehabilitation Hospital.

S. Miyake : Department of Pediatrics, Yokohama City University School of Medicine. 
児童相談所による巡回訪問(肢体不自由施設の専門医師) がほぼ年に 1 回行われて招ります。教育サイドと連けい した医療システムは, 本年度より養護学校分校となった ため, 現在, 整備・進行中です.

\section{II-B-13. 重症心身障害児の下肢交叉につい $\tau$}

愛知県心身障害者コロニーこばと学園 篠田 達明 岡田 喜篤、夏目 和子 福嶋 正和 村地 俊二 野上 宏 沖高司萩野 武彦 夏目 玲典

いわわる重症心身障害児（以下重障児と略す）の異常 肢位のひとつに下肢交攴がある.われわれは愛知県心身 障害者コロニーこばと学園に 54 年 4 月 1 日現在入所中 の 170 名の重障児を対象として, この下肢交叉の有無と これに因る障害の実態を調查した。この結果，下肢交叉 は 8 歳から 33 歳までの 37 例 $(22 \%)$ に存在し, 脳性麻 痺巟と小脎髄症に最も多くみられた。

この下肢交叉は二型に分けることができる，そのひと つは重度痓性麻痺にみられるもので, 背臥位に拈ける緊 張性迷路反射の持続により, 下肢の伸筋群が優位とな りこの結果生じたものと思われ，いまひとつは変性疾 患など自発運動の欠如から起こる高度の関節拘縮のため 下肢交叉をきたしたものである。

この下肢交叉はつぎのごとき障害の要因となってい た。(1)介護上：ズボンや下着があてにくい，执むつ交 換がやりにくい，らつぶせや座位をとらせにくい. (2)

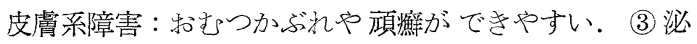
尿器系障害: 内外尿道口を圧迫するため, 尿が出にく い, 尿もらしを起こしやすい，膀胱内圧の上昇がみられ る. (4) 運動器系障害 : 痤性股関節脱臼の招来と下肢の 運動発達を阻害する. (5) 生殖器系障害 : とくに 12 歳か ら 22 歳の思春期の男子に下肢交叉の結果と和もわれる 睪丸の皮下脱出がみられた。いずれも内在性脱出, すな わら，睪丸がそけい管を通って腹腔内へ入る症例はな く，すべて表在性脱出に分類されるものであった．ほと んどが緊張のつよい重症度脳性麻痺にみられること, ま た幼少児にはみられぬことから，緊張性迷路反射によ り，睪丸がたえずはさみつけられ，睪丸の皮下脱出が起

13) The Leg Crossing Posture in the Profoundly Retated.

T. Shinoda, K. Okada, K. Natsume, M. Fukushima, S. Murachi, H. Nogami, K. Oki, T. Ogino, R. Natsume: Aichi Prefecture Colony for the Mentally and Physically Handicapped.
こるのではないかと推測した。なお 22 歳の 1 例は左睪 丸捻転症に陥り，観血的に睪丸を剔出した。肢交叉の 予防と治療として，患児を腹臥位または側臥位に保つこ と, Spreizhose や股外転アパラートの使用, 股内転筋 レリースの方法などについて述べた.

<質問>千葉県袖ヶ浦福祉センター療育園上原 朗：下肢交文を示した症例のほとんどが CP 拉よび近 似疾患であったとのことですが，交叉の強かった症例の 股脱は，両側性が多かったでしょらか？ 私達の調查で は，両側股脱がほとんどでその発生は 1 歳前半から出は じめ $3 \sim 4$ 歳で出来上がってしまらものが多く，そのま ま放置すると今回発表のような重度重心児（者）になる ことが多いので，できるだけ早期に加療すべきと考えて いをす。

<答〉篠田 達明：下肢交叉を呈した重度脳性麻瘦に

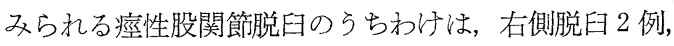
左側脱臼 1 例叔よび両側例 4 例でした。

\section{II-B-14. 重症・重度児の側彎と生活環境}

$$
\begin{gathered}
\text { 東京女子医大リハビリテーション部 山形 恵子 } \\
\text { 寺内 正 三沢 峯茂 遠藤 道子 } \\
\text { 小畑 順一 }
\end{gathered}
$$

都立北療育園整形外科 藤本輝世子 都社北療育園城北分園 高橋 信子

重症・重度児の脊柱変形は年齢と共に目立ってくる傾 向にある，私達は施設や養護学校, 病院リハビリテーシ ヨン部で訓練指導を行った 1,449 名の対象児で, 脊柱変 形，側彎の調査を試みた。

脊柱変形の特に目立った 130 例をレ線撮影し, Cohle 法で測定した。坐位可能な例は坐位で撮影したが，多く の例は背臥位撮影となり，固定したために変形の矯正さ れた例子みられた。 Cohle 法で $20^{\circ}$ 以上を示した例は 55 例で $(42 \%)$, 股関節の脱日を合併していた例は 13 名

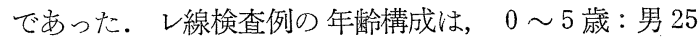
名, 女 12 名, 計 37 名, $6 \sim 10$ 歳: 男 18 名, 女 16 名, 計 34 名, $11 \sim 15$ 歳：男 15 名, 女 21 名, 計 36 名, 16 〜20歳：男 10 名, 女 13 名, 計 23 名である.

14) The Incidence and Treatment of Scoliosis in Physical and Multiple Disabilities Child.

Y. Yamagata, T. Terauti, M. Misawa, M. Endo, J. Obata : Tokyo Women's Medical College.

T. Fujimoto : Tokyo Municipal Kita Ryōikuen.

N. Takahashi : Tokyo Municipal Kita Ryōikuen, Day Care Center of Jōhoku. 
$20^{\circ}$ 以上を示した 55 例を年齢別にみると， 0 〜 歳 7 名, $6 \sim 10$ 歳 12 名, $11 \sim 15$ 歳 19 名, $16 \sim 20$ 歳 17 名之 11 歳以降に増加傾向がある.

$20^{\circ}$ 以上の側彎を示した例を障害部位別にみると，四 肢麻痖が多い $(80 \%)$. 側彎側の病名別では, 脑性麻痺 が多く(70\%) みられた。

親の生活習慣調査では，常に左手で抱いて介助をする と答えた 39 例 $(35 \%)$ の中に右突 C 型側彎が多い傾向 をみた。車椅子に乗せた際の盎柱変形は親, 介助者とも 約 70\%が気付いていたが，子供の好导姿勢と思い特に 不信に思っていない例が多かった．私達が施設や学校で の健康管理面で注意が不足していたことを痛感する．重 症・重度児の生活環境は, 親や介助者の理解, 協力で左 右される。姿勢と誤飲の関係や胃液の逆流に伴う食道潰 瘍なぞ，次々に問題が提起されている.

乳幼児期から, 正しい姿勢の保持と生活習慣の調整, 異常姿勢反射のコントロールにより，少しでもこれらの 変形を予防しなければならない。

<質問>国療下志津病院 斎藤篤: (1) 重症心身 障害児用の車椅子の最も安全で有効な型について，また 入手法についても御教示下さい。(2) 脊柱側彎の, 進行す る因子としての春柱構成筋群の変性率引以よる未梢神経 障害についての御意見を和願いします。

<答>山形 恵子：(1) 車椅子は手動, 電導とも転用 可能です. (2) 側彎変形の問題は今後に 検討を加学報告 したいと考㝋すす。

く追加〉愛知コロニー 篠田 達明: わたくしどもは 重症心身障害児の側彎症の車椅子処方には従来より苦心 しているが，スライドに示された，外国製車椅子は，と くに㽷性のつよい, 重度の側彎症児の頭部を固定するに は，きゃしゃすぎて，実用にはむずかしく，あえて輸入 するほどのものではないと思います。

\section{II-B-15. 脳性麻盘幼児の身体機能的予後 一主として日常生活動作につい $\tau$}

埼玉県生活福祉部 五味 重春・洁力筑波大 学心身障害学系運動障害研究室

脳性麻㽻（CP）䝨の日常生活動作（ADL）確立は, リハビリテーションの第一歩であり，それには身体的機

15) A Functional Prognosis of Young Children with Cerebral Palsy, Especially on A.D.L. S. Gomi, et al. : Medical Consultant, Dept. of Welfare, Saitama Prefecture, Tsukuba Univ. Faculty of Defectry.
能を主体とし，その他種々の要因が関連すると考えられ る.

今回は幼少期に著者が評価・指導した CP 児 111 名 の身体機能 (Johnson, Zuck の運動年齢) と現在の ADL の関係などを検討した結果を発表した。調査方法は予報 抄録の如くにつき省略し, 結果の概要のみを述べる.

1 ）母子入園時の年齢は，2 歳〜 6 歳にわたるが， 3 歳〜 4 歳台が 69 名 $(62.0 \%)$ であった。病型分類は, 痤直型 50 名, アテトーゼ型 57 名, その他 4 名である. 現在（昭 53. 11）年齢は，13〜22 歳にわたり 16〜18 歳 台が 55 名 $(49.6 \%)$ となっている.

2）母子入園当時に ADL のらち自立している項目 は，食事動作のみが大部分（41名）であった。

3 ）現在の ADL では, 独歩, 入浴動作を除く 7 項 目（食事, 脱衣, 着衣, 洗面, 書字, 排便, 排尿) は, 概ね 50 〜 $60 \%$ が完全自立し，その他は一部介助，全介 助 (約 $30 \%)$ である。

4 ）母子入園時の身体機能すなわち運動年齢〔Lower Motor Age (LMA), Upper Motor Age (UMA)] と 現在の ADL については，大きな関連が認められた。 すなわち LMA と歩行, UMA と各 ADL 項目に関 してである．例えば入園時の LMA が 12 力月以上のも の(33 名) は， 3 名を除き歩行（杖歩行を含屯）可能で あり，LMA 7 カ月未満のもの（27名）は，全員歩行 不能で車椅子に依存している.

また入園時 UMA が 21 力月以上のもの（63名）で は, 食事動作に怙いて自立 57 名, 一部介助 5 名, 全介 助 1 名である. しかし UMA 7 カ月未満では, 24 名の らち自立 1 名, 一部介助 4 名, 全介助 19 名である。 そ の他の ADL 項目についても, UMA と関連が高い.

5 ) $\mathrm{ADL}$ 自立度の高いものは, 学業成績, 友人関係 に括いて好ましい傾向を示したが，ADL 自立度と親の 養育態度に関連はみられなかった。

\section{II-B-16．喫食困難巟への対応}

松江整肢学園 杉谷 晃俊 鳥取大学脳神経小児科 北原佶

脳性麻㾝, 特に Dystonia の場合は各種喫食障害を起 こし易い。この際，採り上げたのは主に，契食時，牙関 緊急の状態になる者，及び反対に開口が過大で，開口時

16) Treatment of Feeding Disabilities.

A. Sugitani : Matsue Prefectural Crippled Children's Hospital.

T. Kitahara: Section of Child Neurology, Tottori Univ. School of Med. 
口狭部が閉鎖し難いために誤燕を起こすのではなかろら かと思われる症例である。

まず，これの解決策の足掛りとしては，前記いずれの 症例も, 喫食のための開口時, 口狭部が同時に開き誤燕 を起こし易く，前者は防御反応として口を閉じ，後者は その現象そのものではなかららかと考光, 開口したまま 口狭で口腔と鼻咽腔を遮断する方法を考えた。

前者に対しては，願部等より facilitateして開口さ せ，これを術者の手掌で覆って強制的に鼻呼吸に切り換 えれば，その裡に切り換わったことが手掌へ加わる陰陽 圧の消失で感じられると同時に，患児の呼吸も楽にな る. 切り換えが完了すれば口を開放して鼻をつまみ，口

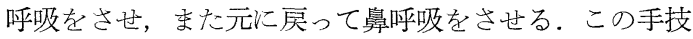
による効果は顕著なものがあった。

後者に対しては，前記手技は余り効果的ではなかっ た。すなわち，強制的鼻呼吸に切り換わり難かったた め, 直接舌根部への冷水を滴し込又刺激を加えることに より，咽頭閉鎖および與下反射を起こすべく企画した。 結果は少々馴れれば舌根部へ水を溜め，一気に飲み込む ことができ，喫食事にそれなりの効果は上がっている が，完全な解決には至っていない。こ机は Dystonia の 常として環境の変化に影響され易いためであろらが，與 下運動第 1 相の口腔より㸶頭へ食物を送り込む舌の運動 不調が遺されているためであろう。

な括による，食物の 投入拒否の状況に対しては， 「くまり胆」を濃く溶き，これを指につけて舌背部を擦 り，舌を口腔底に展開させたところ，つき出し現象等は 比較的早期に消失し，また，舌の微妙な運動も引き出せ そらであるが，與下第 1 相委でには効果は及んでいない よらである。

\section{II-B-17． 脳性麻痺に 対するフェノールブロ ック効果判定について}

秋田県立太平療育園 高浜 正人 菅原 正信

脳性麻疩児のリハビリテーションでは㽷直のコントロ ールが大きな問題となる。今回, 我々は歩容の改善を目 的として脛骨神経のフェノールブロックを行い，筋電図 学的にブロック効果の判定を試みたので報告したい.

脛骨神経の経皮的ブロックには電気刺激端子のついた 絶縁電極注射針を用いた。 $3 \%$ フェノール溶液を 3 $5 \mathrm{ml}$ 注入し，足関節背屈筋の強化を主体とした機能訓

17) Evaluation of the Phenol Block for Cerebral Palsied Children.

M. Takahama, M. Sugawara : TaiheiRyoikuen, Akita Prefectural Hospital.
練を行った。

効果判定のため，ブロック前と 1 力月後に足関節背屈 時の前脛骨筋と腓腹筋の積分筋電図から両者の比率を算 出し，拮抗筋活動指数として数量化した。被検者は膝 $90^{\circ}$ 屈曲位で固定し， 3 秒の積分時間のあいだに可能な だけ背屈運動を行わせた。

対象は㽷性歩行がみられる痤直型片麻瘴，両麻㽻およ び混合型麻㽻の 17 名で 21 肢である. 痓直型麻痺では 1 力月後の検查で拮抗筋活動指数や足関節背屈可動域の増 加を示すものが多く，とくに症例の約半数に急激な上昇 がみられた。混合型麻痺では足関節背屈可動域は一様に 増加しているが，拮抗筋活動指数の変化は不定で，あま り変化のないものや低下している症例もいくつか認めら れた。

痤性歩行は下肢筋群の協調性の乱れからくるもので, 治療面からも主動筋と拮抗筋のバランスをチェックする ことは必要なことだと思わ机る，筋電図積分值は必ずし も筋力を表わすものではないが，痤直型麻痺ではある程 度の相関が足関節背屈筋活動量との間に考えられる。 た，測定時に非生理的な肢位に固定することは，歩行と いら協調運動を必ずしも反映していないことも考觉ら れ，歩行時の機能的測定法について検討中である.

\section{II-B-18．起立の安定域の検討—－（1）脳性 麻痺における Cross Test}

浜松療護園 月村 泰治 川村 碩涁 田中 健二 池田珠江

重心計による重心動摇記録を重心困として把え，これ を解析検討して定量的機能評価法の一つとして臨床的に 応用してきた。今までは直立位の不安定性を把えて評価 するために計測足位を一定にしたが，今回は起立の安定 性を評価するために安楽足位（被検者が一番安定感を感 ずる直立足位) をとらせて cross test を行った。重心 図に打ける起立の安定域の拡がりと pattern, 移動の距 離，方向性など，いろいろな面から検討を行ってみた。

1) 健康成人に捻いて Romberg posture, 前方 $60^{\circ}$ 開角足位沶よび安楽足位の 3 足位で重心図を記録した。 直立 20 秒間に执汓る重心図の面積および動摇軌跡の移 行距離は安楽足位において最低の值を示したので，今回 は安楽足位における cross test を実施した。

18) Safety Area of Standing-(1) Cross Test for Cerebral Palsy.

T. Tsukimura, H. Kawamura, K. Tanaka, T. Ikeda : Hamamatsu Crippled Chidren's Hospital 
2 ) cross test は直立 10 秒後, 前方, 後方, 右側, 左側に身体を傾斜し，体重心を移動させて重心図を記録 する方法である. 正常の場合, cross test の重心図は直 立時の重心図を中心とする比較的規則正しい十字を描く 重心動摇を示す. 正常成人の場合, 前後和よび左右方向 之己足長, 足幅の $60 \%$ 前後の shift が可能で, 安楽足 位, 開眼時が最大值を示す．また側方 shift はすべて前 方寄りである.

3) 脳性麻疾で機能的に 良好な病直 A 群では十字を 描けるが，比較的こじんまりとしており，前後方向では 正常の $70 \%$ 程度, 左右方向では $80 \%$ 程度の拡がりを示 す. 角度方向も比較的良好である. 機能的に劣る㾏直 C, D 群では充分な cross を描けず，前後傾際して 重心の shift が逆になるものが多い. 方向性も不定であ る. 緊張のつよいアテトーゼ型では装具着用が多少左右 への shift が可能な程度で充分な cross test はできな い. rotation を兼㸚たかたちの body sway を示し, standing instability が即, 起立の安定域の感があり, 両者の間の差が極めて小さいことが知られた。

その他の知見については次回に報告する予定である.

\section{可 動 域}

座長 九州労災病院 長尾 竜郎

\section{II-B-19 21}

\section{II-B-19．健康人の関節可動域について— 年齢・性別による変化}

熊本大学病院理学療法部岡部とし子 佐賀医科大学整形外科渡辺 英夫 熊本大学整形外科 天野 敏夫

実際の診療に際して関節可動域が年齢や性別によって 著明な差がみられる関節があったり，日本整形外科学会

19) The Range of Joint Motions of the Extremities in Healthy People--the Difference According to the Age and the Sex.

T. Okabe : Department of Physical Therapy, Kumamoto University Hospital.

H. Watanabe : Department of Orthopaedic Surgery, Saga Medical College.

T. Amano: Department of Orthopaedic Surgery, Kumamoto University Medical School.
と日本リハビリテーション医学会で定めている正常值 (以下学会值之略す)が必ずしも妥当でない関節も少なく ないといらことに気づき，健康人の四肢の 6 大関節の可 動域測定を行った。

<調查対象之調查方法>調查対象は新生児より 80 歳 未満までの健康と思われる人で男性 328 名, 女性 296 名 の合計 624 名で測定した。

関節角度の測定は 50 単位で行い，方法は学会法に準 じた．それぶれの実測值については年齢別・性別に統計 的に処理 し平均值・標準偏差・信頼区間 $(p>0.95)$. 性別による有意差検定（ $\mathrm{t}$ 検定 $\mathrm{p}<0.05 ）$ を行った。

く結果＞年齢による差が 著明であったのは肩関節外 旋 - 水平伸展, 股関節伸展 - 外転 - 内転 - 外旋 - 内旋, 足関節背屈であり, 年齢差が少ないものとして肘関節屈 曲, 前腕回内 - 回外, 手関節背屈, 膝関節屈曲 があっ た。

性差においては全般的に女性の可動域の方が大きい值 を示す傾向にあり, 特に肩関節伸展・水平伸展, 肘関節 伸展, 股関節内旋, 㮏関節伸展, 足関節底屈で著しかっ た．逆に著明に男性の方が大きい值を示すものは股関節 外旋のみであっだ。性差があまりない動きとしては肩関 節外転・外旋・水平屈曲, 前腕回内があった.

左右差はみられなからた。

学会值より大きい值を示したものは肩関節伸展・外 旋 - 水平伸展, 手関節背屈, 股関節屈曲, 膝関節屈曲, 足関節背屈・底屈であった。

\section{II-B-20. 正常児の Joint Laxity について}

熊本大学整形外科 天野 敏夫 熊本大学病院理学療法部岡部とし子 佐賀医科大学整形外科 渡辺 英夫

近年小児関節疾患に括いて Joint Laxity との関連が 問題にされている.しかし Joint Laxity の判定にはま だ確立した方法はなく種々のやり方が行われている. 我 我は今回多くの方法の基本になっており，末た一番良く 利用されている Carter の方法により正常児について調 ベ, その問題点, 適用方法について検討した。調查は生後 1 週以内の 新生児より 12 歳をでの合計 1,200 名につい て行い, 計測は 3 人の検者により行った. 角度は 5 度単

20) Joint Laxity in Healthy Children.

T. Amano: Dept. of Orthopaedic Surgery,

Kumamoto Univ. School of Med.

T. Okabe : Dept. of Physical Therapy, Kumamoto Univ. Hospital.

H. Watanabe : Dept. of Orthopaedic Surgery, Saga Medical College. 
位にて測定した。

<結果＞5 項目全部陽性を示したものは $2 \sim 3$ 歳にか けてピークを示し 1 歳未満, 5 歳以上ではほとんぞみら れなかった。 3 項目以上陽性之 4 項目以上陽性について は類似した年齢的推移をたどったが，1歳未満のもので は 4 項目以上陽性は2られず，3 項目以上陽性を示した ものは 6 力月以後増えはじめ, 2 歳台で最も多く $75 \%$ と大半にみられた。 また Carter の基準を利用して Joint Stiffness 評価の試みを行ってみたが， 5 項目中 0 項目を含を 1 項目以下陽性のものと 5 項目全部陰性のも のでは, 年齢が高くなる程増加する傾向がみられた。新 生児, 3 力月児, 2 歳台で最も少なかった. 項目別にみ ると拇指屈曲と足関節背屈に関しては新生児で全例に陽 性にみられた後は, 年齢と共に陽性率は下降した。膝関 節伸展, 肘関節伸展, 手指伸展関しては新生児で陽性 に出ることは汪とんどなく，年齢と共に変化するパター ンも伸展の 3 項目では, 各々異なった経過を示した. 伸 展の 3 項目共 1 歳台で最も強く変化した。

《結語>Carter の方法で Joint Laxity 陽性という 時は4 項目以上をとるべきである. また Carter の方法 は1歳未满の Joint Laxity の判定には不適当である. また Joint Stiffness 判定の指標として0 項目を含さ1 項目以下の陽性かまたは全項目陰性をと机ば応用でき, これは一つの方法で Joint Laxity と同時に Joint Stiffness についても考えることができるので便利であると 思われる。

<質問>名古屋市立大整形外科 船橋 建司: 関節可 動域拉よび Joint Laxity の年齢差とか性差は, 何に起 因するのでしょらか。たと党ば関節形態の変化, hormonal な変化が主因なのでしょらか.

<答 $>$ 天野 敏夫：Joint Laxity の年齢的変化の原 因として，(1) 1 歳未満では胎内での肢位のために屈曲拘 縮傾向が残っていること, (2) 1 歳台では身体発育の結果 活動性が増し, 伸展傾向が段々増していくこと, (3) 2 歳 台で最もJoint Laxity が著明にみられた点に関しては 身体活動性の増加の他に, 例えばホルモン等による内因 性の factor が関与していると思われる。しかし Carter の方法で新生児に Joint Laxity がなかったからといっ て真にないわけではなく, 屈曲方向のみみると新生児に 最も Laxity が強い.

\section{II-B-21。他動伸張三手技が 指床間距離（脊 柱前屈）に及ばす影響}

\author{
九州学災病院 和才 嘉昭 \\ 産業医科大学 緒方 甫
}

平均年齢 50.9 歳の成人男性 15 名の, 軀幹柔軟度々く に脊柱前屈に影響を及ぼす，1）脊柱起立筋群，2）股 伸展筋群，3）膝屈筋群，のそれぞれに対する，下肢側 より求心性に 3 手技をつつける $\mathrm{A}$ 手法と, 軀幹側より遠 心性に逆に 3 手技をつづける B 手法の, 他動伸張二手法 の結果は, 現在臨床の場で広く便宜的に 採用されてい る, 長坐位と起立位て測定した指床間距離から考察する と, 次のごとく言えよう.

（1）A法B法共に伸びに大差はないが，全体的に汸 A法が若干よい (A法 $5.49 \mathrm{~cm}$, B 法 $5.09 \mathrm{~cm}$ ).

（2） A 法B 法共に第 1 手技に执いて伸びが最もよい 〔 $\mathrm{A}$ 法 $2.40 \mathrm{~cm}$ (膝屈曲筋群) $\rightarrow 1.77 \mathrm{~cm}$ (股伸展筋群) $\rightarrow$ $1.40 \mathrm{~cm}$ (脊柱起立筋群), B法 $2.27 \mathrm{~cm}$ (脊柱起立筋 群) $\rightarrow 1.50 \mathrm{~cm}$ (股伸展筋群) $\rightarrow 1.40 \mathrm{~cm}$ (脊柱起立筋群) ].

（3）対象笳群位対する各々の手技の効果は，筋電図 に执いて明確であるが，A法，B法共にいずれの手技に おいても，市べての筋群に効果は波及している。従って 単一筋群低対する単独伸展は不可能である.

（4）下肢の肢位， とくに股屈曲角の増加は $\mathrm{L}_{5} \sim \mathrm{S}_{1}$ 間の角度や腰仙角度に大きく影響し, 前者で約 $7^{\circ}$, 後 者で約 $12^{\circ}$ と変化が認められた. 従ってA法, B法共に 第 2 手技では股伸展筋群よりむしろ脊柱起立筋の伸びに 影響する。

（5）長坐位と起立位で測定した指床間距離の值の差 は, 肢位の安定性の関係からか長坐位の方が, 平均 $1 \mathrm{~cm}$ の差で長く記録されている。

(6) 伸張手技は第 2 手技をの朰き, 膝関節屈曲防止 が肝要である. この防止策としては被検者, 術者共に上 肢での下肢固定を活用するとよい.

（7）指床間距離の測定は，とくに長坐位では膝屈曲 による下肢の挙上, 起立位では股屈曲による殿部の後方 突出と，膝屈曲などの，それぞれの代償を防止しなけれ ばならない。

以上が今回の実験を通じ把握できた項目である。諸氏 の参考にな机ば幸である。

21) Basic Three Technics of Passive Stretching Exercise for Trunk Mobilities and Finger Distance.

Y. Wasai : Kyushu Rosai Hospital.

H. Ogata : University of Occupation and Environmental Health, School of Medicine. 
<質問>長崎大学整形外科篠田 㑆: 我々も $\mathrm{Lu}-$ mber flexibility を表わす示標孔じて，指床間距離 (FFD) と第 7 頚椎棘突起より Jacobzline ホでの経皮 的距離の $1 / 5$ の長さを測定し，その伸張度を測定してき たが，FFDは骨盤の代償運動も加味される. そこで Lumbar flexibility の index として, 距離(腰仙部) の測定が better と考えるが，先生はどのようにお考え でしょらか。

<答〉和才 嘉昭：もちろん必要である. 但し今回は 軀幹前屈に拮抗する, 春柱起立筋群, 股伸展筋群, 膝屈 曲筋群の, 生理的筋トーヌスの如何に焦点をしぼった関 係からこのようにまとめてみた。

\section{その 他}

座長 日本医科大整形外科 石田肇

\section{II-B-22 26}

\section{II-B-22. 通電治療と痛覚閾値の測定}

都立府中病院神経内科 花籠 良一宮本 和久 Swiss Paraplegic Centre, Basel, Guido A. Zäch

知覚障害の病態を検索し, かつ薬物療法, 物理療法な ぞ効果の客観的評価を目的として, 輻射熱痛覚計（pain meter NYT-5）を用い各種疾患の痛覚䦪值を検討した。 方法は被検者を安静背臥位とし, 測定部位を黒くぬり, 痛覚計へッドの空から輻射熱を照射し，温かみからだん だん熱い, 最後に痛みと変り, 耐えられないと判断した 時に押すスイッチで，熱照射が遮断されるよらになって いる.

<結果 $>こ の$ 痛覚計では単位時間当りの熱量と疼痛閾 值潜時との間には, 単位面積当りの $\mathrm{mcal} \times \mathrm{time}=$ const. (mcal $/ \mathrm{cm}^{2}$ ) の関係が, $200 \sim 500 \mathrm{mcal} / \mathrm{sec} / \mathrm{cm}^{2}$ 間の測定が成立することがわかった，今回の成績では正 常者に比較して, 三叉神経痛が最も痛覚閾值が低下して おり, ついで脊損, 脳卒中後片麻瘏, スモン, 糖尿病性 ニューロパチーの順となっていたが，正常者とスモンを

22) The Pain Threshold and Transcutaneous Nerve Stimulation for Pain Control.

R. Hanakago, K. Miyamoto : Department of Neurology, Tokyo Metropolitan Hospital of Fuchu.

Guido A. Zäch : Swiss Paraplegic Centre, Basel.
除いて症例が少ないので今後検討を要する。また 200〜 $500 \mathrm{mcal} / \mathrm{sec} / \mathrm{cm}^{2}$ での測定点において，疾患により正 常者と異なったパターンを示す視床症候群を呈する脳血 管障害などは病態生理学的に重要と思われる.

今回知覚異常を伴ら数種の疾患を対象に, 新しい通電 治療の痛覚閾值に及ぼす影響について検討したが，この 治療装置は山形波と矩形波の合成波から成っている。三 叉神経痛の例では局所の通電治療後では痛覚閾值の上昇 が認められた，その他痛覚過敏状態にある場合は，通電 後闌值の上昇傾向がみられ，一方知覚鈍麻痺に近い状態 では閥值の下降傾向が認められた。しかし必ずしも正常 領域に収束すると言い切ることはできない. 特にスモン の如く自発性異常覚と一見表在覚の低下があるようで も, 痛覚計では閾值の低下しているょらな場合は, 治療 後の影響は複雑である。な扎痛覚計による測定では，正 常者であっても, 痛覚閾值の低下状態にある患者につい ても, 鎮痛剤使用後の変動推移は明瞭に閾值の上昇を認 めた。

＜質問＞慶応大月が瀬リハビリセンター 石田＼cjkstart暉 : 私共の症例では効果のあった 20 例の内 $40 \%$ に治療終 了後に遷延効果が認められた。通電治療後に痛覚に閾值 を経時的に測定した症例があれば，その変化を教えてい ただきたい。

<答 $>$ 花籠 良一: 臨床効果之痛覚閾値測定上の変化 については，各疾患ごとに異なるが，臨床的に疼痛が改 善し易い，単純な機能的痛みなどは，極めてよく結果が 一致する。つまり閾值の低下が，治療後上昇がみられ る.

\section{II-B-23. 疼痛に対する 経皮的電気刺激の 治 療効果}

慶応大月が瀬りハビリセンター 石田＼cjkstart暉 慶応大リハビリセンター 千野 直一

30 名の疼痛を主訴とする患者に対し，経皮的電気刺 激治療を行い, 刺激部位, 周波数等のパラメータについ て効果の比較検討を行った。

疾患の分類は Picaza の分類に従い, I 群 : 末梢性, II 群 : 脊髄・中枢性, III 群 : 外傷・術後, IV 群 : その 他，に分けた。

<結果 > 対象患者 30 例中, 著効及び疼痛の軽減を示

23) The Effectiveness of the Transcutaneous Electric Stimulation for Pain Treatment.

A. Ishida : Keio University Tsukigase Rehabilitation Center.

N. Chino : Keio University Hospital Rehabilitation Center. 
したものは 20 例（67\%）であった。 I 群は 2 例共に効 果があった．II 群は 9 例中 6 例 $(67 \%)$ に，III 群は 5 例全例に効果が認められた。IV 群は 14 例中半数の 7 例 が有効であった。

効果が認められた 20 例に詨し, 最適周波数と強度を 求めたところ， $30 \mathrm{~Hz}$ 前後で効果のある群 $(20$ 例中 7 例), と $80 \sim 100 \mathrm{~Hz}$ で効果のある群 (20 例中 13 例) に分かれた。疾患群別にみると, II群はすべて高周波, III 群は 5 例中 3 例に低周波で効果があった。 I・IV 群 にはこの差が認められなかった。

13 例に疼痛部及び疼痛部以外にも刺激を行った。 5 例は疼痛部にの及効果が限局し, 未梢神経刺激では 6 例 中 3 例に効果があった。脊髄レベルの刺激・疼痛と関係 のない部位への刺激は全例無効であった．2力所への同 時刺激を 8 例に試みたが, 疼痛部位と末梢神経を刺激し た 2 例の末梢神経障害を除いて, 相乗効果は認められな かった。

効果の出現は 2 例の増悪例を含めて, 半数以上が刺激 開始直後に起こり, 効果の持続は刺激を停止すると直ち に消失するものが多かった。しかし，8例に打いては， 刺激終了後の遷延効果が認められた。 心理テストは, 矢 田部一ギルフォード，CMIを用い15 例に施行したが, 治療効果と一定の関係は認妨れなかった。

以上の如く, 短期間治療に打汀る効果は認められた。 今後, 長期間治療後の効果の減少の有無, 及び同一疾患 内に抢汸年ラメー夕による効果への影響等を比較検討 する予定である。

\section{II-B-24. リハビリテーションにおけるハリ 治療について}

自治医大リハビリセンター 大井 淑雄 井上 和彦 西岡久寿樹 吉田 輝明 篠崎 直子 谷岡 淳

鎮痛㧍よび除痛の目的で通電式ハリ治療を行っている ので臨床的見地から経験を報告する. 症例は膝痛 25 例, 腰痛 30 例, 頸痛 27 例, 肩痛 16 例, 春䯣損傷による痛 み 6 例, そして片麻痺による痛み 7 例の計 111 例であっ た.

<方法〉温熱や薬物療法等によっても满足のいく効果 の得られない痛みに, 疼痛部分に 4 本のハリを刺入しパ ルスジェネレーターにより約 30〜60 分間の通電を行っ

24) Acupuncture Therapy in Rehabilitation.

T. Ooi, K.Inoue, K. Nishioka, T. Yoshida, N. Shinozaki, J. Tanioka : Rehabilitation Center, Jichi Medical College.
た。 ハリ治療の効果に 満足している症例は䐂痛では $72 \%$, 腰痛では $70 \%$, 頚痛は $74 \%$, 肩痛では $88 \%$, 脊 䯣損傷に上る痛及では $100 \%$ ，そして片麻疾に上る痛み では 57\% であった。全 111 例中では 75\% に八リ治療効 果が認められた。このシリーズはハリ治療が secondary choice であるが, 治療の first choice にすれば, 比率 は増加するであろう。 ハリ治療効果が認められた症例の うちほとんどは, 第1回の治療で何らかの効果が現われ ている.よって10回位やっても効果の出ない症例は慢 然と治療を続けるべきでない.

1 回のハリ治療によってその治療効果はどの位の期間 継続したかてついて検討した。効果のあった症例中 $76 \%$ は効果の持続が 1 日以内であった。 外来日数, 患 者数なぞを考えると 2 日位の継続が理想的である. 従っ て，期間が長くなるような努力（たとえばマイナートラ ンキライザーの投与）が必要である。治療効果のあった 10 症例については, ハリ治療の直前と終了 1 時間後に 採血を行って血液成分について検討した，血液成分は， 前・後ともに正常值域内に存在し, 变化は全例とも軽度 であった。

現状ではハリ治療は対症療法であり，その治療機序に ついては，まだ不明な部分が多く残されている。今後は ハリ治療の適応について臨床的アプローチを進めていき たい。

<質問 >兵庫県りハビリセンター 南 久雄 : (1) 脊損患者の疼痛に詨して $100 \%$ の效果を出しておられま すが，実際的な方法（刺入部位，数等）について书教え 下さい。

<質問>千葉労災病院 小野 美栄：(2)脊損の疼痛 に対し効果があったのは麻痺域の疼痛であったか?

<答 >井上 和彦：(1) 脊損では知覚麻痺であるので 痛みがないはずであるが，同部位に痛みを訴える場合が ありこのような, 疼痛機序のはっきりしない痛みに, 痛みを訴光る部位に 4 本の針を刺入し，1時間以上の通 電を行った。 6 例のらち100\%の改善を得た。（2)全例 麻痺部位の痛みに対して行った。 


\section{II-B-25. 肢体不自由児（児童生徒）の身体 特性と福祉関連機器活用状況から みた医療・社会学的視点}

（演題中止）

\section{II-B-26. 大学病院リハビリテーション部の 現状と今後の問題点}

$$
\begin{gathered}
\text { 聖マリアンナ医大整形外科山崎 誠 三好 邦達 } \\
\text { 長尾 悌夫 加藤寿太郎 南郷 明徳 } \\
\text { 笹 益雄 }
\end{gathered}
$$$$
\text { 聖マリアンナ医大リハビリテーション部 }
$$

谷内 文子 牧田 光代 古沢 早苗 丸田外美江

昭和 49 年 2 月附属病院の 開院と 同時にリハビリテー ション部む開かれた。当初のスタッフは RPT 2 名, 兼務医 4 名で, 部長は整形外科, 副部長として内科, 外 科，整形外科から各 1 名である。 OT 業務の開始は昭 和 50 年 12 月で, 53 年度末の スタッフは RPT 6 名, OTR 3 名, 受付兼補助者 2 名よりなり, 常時 3 名の MSW の協力を得ている. リ八部患者数は 48 年度は 1 カ月半であるが 57 名, 49 年度は 547 名, 53 年では 1,699 名と 増加し女性患者の 増加が目立っている. 外 来, 入院患者総数代対するリ八患者の占める割合は, 53 年度では 273,661 名の外来に対 し $0.45 \%$ ，入院は 207,503 名に対し $0.21 \%$ で，開院以来漸増傾向にある. 疾患別では, 腰痛, 頸腕症候群, 関節疾患などの整形外 科的疾患が，全体の約半分を占めている。これは，我々 の治療方針が薬物療法に優先して，運動療法をとりあげ ているためであり，外来患者の軽症例では, Home exercise をすするている. 疾患別の増減を年度別にみる と, 退行変性を主体とした, 脊椎関節などの変形症の増 加がみられ，年齢別にみても 40 歳以降の 年齢層の増加 がこれを裹付けている．指示を出した科别の年度推移を みると、リ八部の正しい認識が得られなかったこともあ り, 当初は整形外科学療法室的存在であった。 しかし, 昭和 53 年度ではほぼ全科から指示が出るようになり, 次

26) Problems in Rehabilitation of University Hospital.

M. Yamasaki, K. Miyoshi, Y. Nagao, J. Kato, A. Nango, M. Sasa : Department of Orthopaedic Surgery, St. Marianna University School of Medicine.

F. Yauchi, M. Makita, S. Furusawa, T. Maruta : Department of Rehabilitation, St. Marianna University School of Medicine.
第にリハビリテーションの正しい理解が得られてきた。 リ八部の 患者動態を検討するために次の 3 点が 問題之 なった，1）リ八の正しい理解，2）卒前・卒後教育の 必要性，3）大学病院リ八部の限界である１）の問題 は，2）の教育問題の解決がなければ，容易に解決され ないるのと思う。すなわちリ八専門医による教育, 研究, 診療がリ八部を独立させ，よりよい理解が得られる。

3) は昨今の社会情勢をみる時，また大学病院の性格を 考える時，中間施設ナーシングホーム等の充実が望まれ るところである。

\section{建 築}

座長 宮城県拓杏園 今田 拓

B-II- $27 \sim 30$

\section{II-B-27: 一般病院におけるリハビリテーシ ョン部門の建築計画に関する研究}

東京都老人総合研究所リハビリ医学部障害研究室 林王子 児玉 桂子

一般病院に抢けるリハビリテーション（以下リハと略 称)・サービスは, ここ 10 数年来, 需要の増加伴い, 医療点数の改善などにより，その建築，設備の抎充およ び整備は著しい，本研究は，全国のリハ・サービス諸設 備を持っている一般病院のリ八部門に関する運営形態 之建築, 設備の内容を把握する目的でアンケート調査を 行った．有効回収率は $28 \%$ で，563 病院である．標本 は全国各地域別に 20\% 30\% の比率で分布しており， 病床規模別，経営主体別より見ても片寄りがない結果が 得られた。

本報告は，その内大学病院（以下大学々略称）とリ八 專門病院について考察を行った。

1) 大学病院の及全国悉皆調查を行った．有効回収率 は37\%であり，41病院である.大学のリ八部門の運営 組織は独立している率が $64 \%$ で他の病院に比べて 2 倍 も高く，形態は中央診療科を取っている病院が $65 \%$ と 一位を示している.リ八病床を持っている病院の比率は 他と変わりないが，平均 48 床の規模で，他より小さい。 職員は有資格者で構成されている率が他に 比べて高い

27) A Study on Planning the Medical Rehabilitation, Department of General Hospital. T. Hayashi, K. Kodama : Tokyo Metropoli$\tan$ Institute of Gerontology. 
が，専任・非専任について見ると，他と同じ比率で, 職員の量的不足が現われている.リ八関係諸室の設置状 沉は，両群とも PT 関係諸室が高い. OT, ADL, ST, 義肢装具室の設置率は大学が他に比べてやや高いが，リ 八面積について見た場合， PT のみ，PT と OT が中 心の 2 グループでは，大学は上位を占めているが，それ 以上の内容になると平均值より低い数值であった. 大学 はサービスの他浡育スペースとしてさらに十分な面積 が必要であるが，末だまだこの条件を満たせない現状 である，2）病院全体がサービスを行っでり，から病 床も全部リ八病床であるという条件を備えた病院をリ八 専門病院と規定したが, 13 病院が 該当した. 平均病床数 は213 床であり, リ八面積の平均值は $1,057 \mathrm{~m}^{2}$ （1 床 当り $5.6 \mathrm{~m}^{2}$ ) であった。 この数值はリ八・サービスに 必要な治療ステーションを設ける最低の広さとして妥当 である. その他，職種別職員数も一応の水集を满たして いることが把握された。

\section{II-B-28. 多種類の 障害者の日常生活動作と 建築設備に関する研究 (2)一入 浴動作における介助群の検討}

東京都老人総合研究所リハビリ医学部障害研究室 児玉 桂子 林 玉子

本研究では排泄動作に比較し研究蓄積の少ない入浴動 作を採り上げ，介助群を中心として入浴動作のやり方や 姿勢の観点より問題の整理を試みた。対象者は郵送調査 によるもの 460 名（昭和 52 年度調査実施, 概要前回報 告), 訪問調查によるもの (53 年度調查実施) 30 名であ る. 入浴形態の分類では場所と自立度より, 浴室への接 近・浴槽の出入・洗体・タオルを絞る・衣服着脱といっ た構成動作のいずれかが介助であれば，入浴介助群とし て扱った。両調查を通じ 3 つ入浴形態がみられ，浴 室内入浴群については郵送調查対象群では $45 \%$, 訪問 調查では $87 \%$ の介助率であった。場所別自立度による 分類の段階では介助群の介助内容は多様であるので, 浴 室への接近形態より刘象者を 4 群に分讬, 主要構成動作 の介助状沉を遂行時の姿勢と合わせて検討を行った．介 助率が一番高いのは移動不可群であり, 各構成動作々も 95\% 前後の介助率と，注汴全介助と言ってよい状態で

28) A Study on Activities of Daily Living and Architectural Equipment of the Multiple Disabled (Part-2)-On Depending Bathing Group.

K. Kodama, T. Hayashi: Tokyo Metropolitan Institute of Gerontology.
あった，次にはいざり移動群，車椅子移動群，歩行群と 続き, 歩行群の介助率は他の 3 群に比べはるかに低かっ た. 各構成動作について介助率の高い姿勢に関しても異 なった接近形態のグループ間で違った傾向が認められ た. 浴室への接近形態別に浴室各部位の建築改造率, 問 題指摘率をみると, 各群とも建築改造が行われていない 場合に高い問題の指摘がみられたが，車椅子移動群に関 しては改造率の高い項目についても高い問題の指摘が認 められた。訪問調查でもこの傾向は顕著であり, 浴室 内で抱き上げ介助の必要な移動不可群・一部車椅子使用 者群に入浴構成動作の介助項目が多いことが認められ, 建築改造が行われていても不適当であるため 2 人介助を 強いられている例が多くみられた。これら入浴全介助者 に対して，大規模な機械化による解決案は試みられてい るが，制約の多い日本の住宅事情に即したきめ細かい方 策が建築䄈よび医療をはじめとする專門分野で検討され る必要性が認められた。

\section{II-B-29．身障施設のベッドに関する調査}

宮城県拓杏園 福田 忠夫 今田 拓 宮城教育大学 岩井昂 小住 兼弘

寝たきりでない障害者の一般ベッドの使用状況を, 療 護施設, 重度更生施設, 更生施設, 重度授産施設, 授産 施設, 福祉工場の 6 種の有床福祉施設を対象にアンケー トにより調査したので報告する。

内容は障害種別にベッドの高さ，ボトム，マットレ ス，寝装品について設問した。

回収状況は発送数 260 , 回答数 163 , 有効回答 147 , 施設 7,051床であった。そのらち寝たきりでないケースは 6, 613 床 (93.8\%), そのらちの一般ベッド使用者は 5,801 床(総数の $82.1 \%$, 寝たきりでないケースの $87.7 \%$ )で あった. 更に去のらち、ベッドの内容に解答いただいた 数は 5,584 床 $84 \%$ であった。寝たきりでないケースで ギャジベッド等の特殊ベッドやベッド以外のものを使用 しているのは 1,029 床 $16 \%$ に過ぎない。

ベットの高さ：ボトムの上から床京で $35 \mathrm{~cm}$ 前後が 臨床的に妥当と思われるが $44 \sim 47 \mathrm{~cm}$ を中心とする広 範な使用分布を示し，全般に高過ぎる傾向を示す．回答 を得た施設の $42 \%$ は二段階以上の高さを隻備している.

29) A Research Related to the Beds of Institutes for the Disabled Persons.

T. Fukuda, H. Imada : Takkyo-en Miyagi Pref.

A. Iwai, K. Koizumi : Miyagi Univ. of Education. 
ボトム : 汗の拡散と座位保持の二要素が両立する必要 があるがアンケートではすのこ板が 4,786 床中 1,976 で $41 \%$ と最も多い。すのこ状であること，木製であるこ とが吸湿性と座位バランスの両面に有効と判断されたと 思われる. 底が一枚板のものは経験的に遅く基準化され た施設添ど敬遠されている傾向がある.

マットレス：硬い詰物によるマットレスが $71 \%$ を占 める.これには畳も含なれるが障害に対する適応と価格 面からもスプリングよりも是とされると思われる.

寝装品： $92 \%$ が敷布団を使用して敊り，ベットパッ トの使用は $8 \%$ 末満であり，これが全国的傾向である こと, またマットレスと寝装品の両方とも施設種別の違 いがあまりみられない。

\section{II-B-30. 「社会福祉進展への具体策」考（そ の 2 )一一寝たきり障害者または老 人の家屋について}

（財）日本リハビリテーション振興会, 社会医学技 術学院 下河辺征平 渡辺 昭二 䈤建築設計事務所 麓佳正

社会福祉進展の具体策としてリハビリテートできない ケースに対する介護の実践を欠くことはできない，今回 は寝たきりケースの家屋についての考察を発表する。

病院・施設での寝たきりケースは主としてベッド上で 介護される，老齢化する社会に対応して，寝たきり老人 の介護はやはり家庭でといらのが意識ある老人達の多く が希望するところである、だがとの時, 和式家屋に一般 型のベッドを持ち込むといらことが，一般家庭に意外に 喜ばれていない，それはベッドは和式家屋の昼間生活空 間を狭めるところにある。

和式家屋と洋式家屋との根本的差異は, 前者では昼閒 生活空間と葠室とは兼用的であるのに, 後者では寝室は 昼間生活空間とは分離されていることである，和室家屋 にベッドを持ち込むことは介護には便利であっても家族 の昼間生活空間を狭める。

昨年我々は, 病院・施設・家庭で寝たきりケースの介 護には発想の転換が必要で, それは, ベッドは寝室, 便

30) Several Contrivances Cooked on Houses of Some Severe Disabled.

S. Shimokobe, S. Watanabe : Japanese Association for Advancement of Rehabilitation, Japanese School of Technology for Social Medicine.

Y. Fumoto: Fumoto Architects and Engineers.
器は便所，浴槽は浴室といら考えをベッドが寝室兼便所 兼浴室といら考光に変えることなりと提唱した. そして それに適応できる省人省力用ベッドを発表した(第 15 回 本会)，そのベッドとてもそのま和式家屋に持ちこを のであれば屋内昼間生活空間を狭めることに変わりはな い.

そこで今回は，和式家屋での寝たきりケース対応策と しては，われわれの省人省力ベッド床が盢ゆか面になら ぶような考方方に立つ畳ゆか改造を提唱する。

そうすることによりさらに次の利点が考㝋られる。 そ れは「寝たきりケースといえども, 自分の枕のレベルに 拡がる盢ゆかが見えることは, まさに消えようとする起 坐への意欲の灯を明るくする刺激になるのではないか. 寝たきりケースを起坐させたいと願ら心は同じ屋根の下 に生活を共にする家族の心の常であろらから，その心と 寝たきりケースの意欲の高まりは幸福な老後につながる であろら」といらことである.

\section{動 作 学}

座長 日本大学整形外科 佐野 精司 埼玉医大リハビリテーション部近藤徹 II-C-1 $\sim 11$

\section{II-G-1. 上肢運動の空間座標解析一三次元 測定と四次元測定の比較}

労災義肢センター 鈴木 祥生 土屋 和夫

今までにも, 上肢運動の測定は写真撮影による三次元 空間座標測定が試みられてきているが, 多大の時間と労 力を必要とするため, 基礎研究の一部に用いられている のみである. 演者らは, ターゲットに赤外線 LEDを 用いたセルスポットと称する平面座標測定装置を 2 台用 い, 空間座標測定装置を構成し, 上肢運動の解析を試み たのでとの構成と結果を報告する. 構成は 2 台の赤外線 カメラを互いに $90^{\circ}$ の角度に設置し， 2 個の基準ターゲ ットにより，レンズ・カメラ系の疑似焦点距離と空間座 標の演算傍数 4 個を得るようにした簡易較正法を考兄 た.この結果は, カメラ設置と演算係数を得るのに 1 分

1) Spacial Coordinate Analysis of Upper Limb Motion-Comparative Study of Three and Four Dimensional Measurement.

Y. Suzuki, K. Tsuchiya : The Labor Accident Prosthetics and Orthotics Center. 
程度の時間で済み, 空間座標値の相対誤差は $\pm 0.5 \%$ 以 内が得られた。 また, 上肢運動（水飲み動作）測定で, 平面座標と空間座標計測による関節角度值を比較した結 果, 前者は投影面の角度となるため, 最大で 8 度程小さ くなり，後者で計測する優位性を示した．

この手法による空間座標測定の利点は，1）１回の測 定データから短時間に, 側方, 前方, 上方からみた測定 点の軌跡が得られ, 動作の再現性, 円滑性などが調べら れる，2）各関節の絶対角度変化が同時に（多点同時測 定）得られ，各関節危度比孔容易に得られる。3）簡易 補正法により，カメラ設置が容易で準備時間が短く計測 時間が短くなった。

などが挙げられ，処理時間の短縮と省力化に有効で, 量 的 ADL 動作解析に適していることが判明した。

\section{II-C-2. 片麻痺上肢の連合運動一一健側から 患側への motor irradiation につ いて}

\author{
東北大学温研・鳴子分院 杉山 謙樹 \\ 佐直 信彦 中村 隆一 \\ 社会保険宮城第一病院杉山尚
}

正常者にて最大努力による随意的持続運動を行わせる とそれに伴った全身性の姿勢の変化がみられる。一側か ら他側への motor irradiation (MI) は一般に幼児期 にみられ，Mirror Movement と呼ばれている。 また，

Gellhorn は肢位によって prime mover と associated muscles が変化することを報告している．そこで，一側 上肢の随意的持続運動が他側上肢にどう影響するか， た，それは片麻痺ではどうなっているかを，肢位の変化 を加えて検討した。

対象は正常者 8 例，脳血管障害による片麻疩 50 例 （左片麻痺 19 例，右片麻痺 31 例）であった。被験筋は 上腕二頭筋 $\mathrm{B}$, 上腕三頭筋 $\mathrm{T}$, 手指屈筋群 $\mathrm{F}$, 手指伸 筋群 $\mathrm{E}$ で, 健側手関節の等尺性 掌・背屈時の患側の EMG を表面電極㴪出記録した。被験者の姿勢は 椅子坐位として, 肩基本肢位, 肘角度 $90^{\circ}$ に他動的に固 定した。肢位は健側（正常者では drive する側）Pro-

2) Associated Movements in Hemiplegic Upper Extremity-Motor Irradiation from NonAffected Side to Affected Side.

K. Sugiyama, N. Sajiki, R. Nakamura : Institute of Balneology \& Narugo-Branch of University Hospital, Tohoku University School of Medicine.

T. Sugiyama : Miyagi First Social Insurance Hospital. nation-患側 Supination (以下 P-S 々略), P-S, S-P の3つの組み合わせで，上方向の運動（P-P，S-P では 背屈，S-P では掌屈）を行わせた。

正常成人でも $\mathrm{EMG}$ 上 $\mathrm{MI}$ が出現し，乞れには肢位 により一定のパターンが存在した．MI は左右対称肢位 なら同名筋, 非対称肢位なら drive 側の肢位によって 決まり，P なら同名筋， $\mathrm{S}$ なら異名筋（同一空間方向） であった。

片麻瘦での MI の異常は肢位の組み合わせで順位が あり， $\mathrm{P}-\mathrm{P}=\mathrm{P}-\mathrm{S}<\mathrm{S}-\mathrm{P}$ の順で異常が出現した。これを 片麻瘏の回復過程, 連合反応の有無から 検討与ると, P-P，P-S では回復 (Brunnstrom Stage Hand) に平 行するが，S-P での異常は全く平行せず，単に錐体路 障害, 下位中枢の release だけではないと推定される。 また，麻疩側間の差異を検討すると，P-P， P-S での異 常出現率には差がないが， S-P での異常は左片麻痺に 多い傾向があった．S-P での異常出現は右大脳半球障 害と関係があり, 運動の空間的制御に関与する高次中枢 の障害を示唆している.

\section{II-G-3．肩の運動分析一一第 2 報}

関東逓信病院整形外科 赤司富紗雄 横山一郎 貞光 俊二 竹広 舜 河井 弘次 同記録写真室 高城 泰彦 東京大整形外科 津山 直一

昨年の当学会に引続いて, 肩関節運動について三次元 映像計測と筋電図学的検討を行った。屃関節の運動とし て, 上肢の前方挙上, 側方挙上, 後方挙上を選び, その 基本肢位上り前, 側方挙上では $180^{\circ}$ まで, 後方挙上で は $90^{\circ}$ までの各可動角度域に打沙る, 上腕二頭筋, 三 角筋, 棘上筋, 菱形筋の筋活動電位の増加パターンを測 定し， 表面電極，及び Fine-wire 電極による結果の各 筋の比較を行ってみた。

Fine-wire 電極では前挙, 側挙, 後挙のいずれの運動 でも運動の初期に上腕二頭筋に拉いて著明な筋活動を認 めた。 また三角筋では Fine-wire 電極で, 後挙筋, 運 動後期に筋活動の著明な増加を認めたが，これが表面電 極とのはっきりとした相違とするには, Fine-wire 電極

3) Analysis of Shoulder Mortion (2nd Report). F. Akashi, I. Yokoyama, S. Sadamitsu, S. Takehiro, K. Kawai : Dept. of Orthopedic Surgery, Kanto-Teishin Hosp.

Y. Takagi : Dept. of Laboratory Data, KantoTeishin Hosp.

N. Tsuyama : Dept. of Orthopedic Surgery, Faculty of Med., Univ. of Tokyo. 
自体の感度, 性能の不揃いや, 電極間距離が不定, の要 素があり，この測定值が果たして充分な信頼性を有すか ぞうかは問題である。たとえ信頼性があったとしても， 臨床的応用漈しては, 非侵襲的な表面電極に利する面 が大きく，むしろ表面電極による信頼性，再現性の改善 が望をしい，我々は臨床面を重視するためにも，今後さ らに検討する予定である.

また今回は，臨床的応用も考慮して，習慣性肩関節脱 臼術後の患者の上腕二頭筋, 棘上筋, 三角筋に対して, この方法による筋活動電位, 測定を行ってみた. 前挙で は二頭筋で $90^{\circ}$ 挙上までに他の二筋より著明な筋電増加 のパターンを示し，側挙では三筋いずれも類似のパタ 一ンを示し， 後挙では棘上筋が運動初期に，また二頭 筋，三角筋は運動後期に電位增をみた。

<質問 $>$ 長崎 大整形外科 鈴木 良平: M. deltoideus の EMG は伸展, 外転, 屈曲運動で同一個所で pick-up されたか.

＜質問＞神奈川リ八センター 安藤 徳彦: 表面電極 で算出した活動放電の 周波数特性を調べると， $100 \mathrm{~Hz}$ 以下の低周波領域がその主体と思われるが，動作分析に 表面電極を利用する場合，その点をどの程度に考慮すべ きか，扮教光頂きたい。

<質問>日本大整形外科 佐野 精司: 三角筋への fine wire electrode は pars acromialis に刺したんで すか。部位が一定していないためのバラッキと思う。

\section{II-G-4. 脩柱・骨盤の動作学的研究}

長崎大学整形外科 篠田 㑆 千葉 剛次
乗松 敏晴 平野 英二 千々岩博文
古田 千事 松坂 誠応 藤田 雅章
伊藤 信之 楢林 好隆 鈴木 良平
長崎三菱病院整形外科 田島 直也

<目的>わ的机は，第 55 回西日本整形災害外科学 会, 第 5 回整形外科バイオメカニクス研究会で，脊柱・ 骨盤の動作学的研究を発表したが，今回は，腰痛の病態 を把握するために, 正常な健康男子 8 例, 腰部症状が主 で根症状のない腰痛症の患者 5 例の前屈動作時の動的姿 勢の研究を行った.

4) Kinesiologic Study of Spine and Pelvis. T. Shinoda, G. Chiba, T. Norimatsu, E. Hirano, H. Chijiiwa, S. Furuta, N. Matsusaka, M. Fujita, N. Ito, Y. Narabayashi, R. Suzuki : Department of Orthopaedic Surgery, Nagasaki University School of Medicine.

N. Tajima : Department of Orthopaedic Surgery, Nagasaki Mitsubishi Hospital.
く方法>スティックピクチャーカメラにて，1秒間 24 コマ連続撮影し， 頸椎部前彎，胸椎部後彎，腰椎部 彎曲，骨盤，足関節の角変位と指床間距離を計測した。 EMG は，動作と同期し，頸椎部，胸椎部，腰椎部の傍 脊椎筋群とハムストリング，前脛骨筋，腓腹筋より表面 電極誘導にて，データレコーダに記録し，積分波を求 めた。 また，同時に，平衡機能計を利用して，体重の前 後, 左右への移動の推移々観察した。

（結果＞1）各筋の筋活動については,「整形外科」と 「災害外科」(第 27 巻 4 号) に, 詳しく述べているので 省略する。

2 ）指床間距離之骨盤の角変位とのリサージュで，正 常群では，スムーズなほぼ同一の軌跡がみられるが，患 者群では，スムーズな軌跡全体のバラツキが大きい。

3) 骨盤の各变位と腰椎部の各変位 (彎曲のパラメー タ）とのリサージュで，正常群では，傾きもほぼ等し く, 同じ部位を占める軌跡を示すが，患者群では，バラ ツキが大きく，軌跡全体が右上方に偏位している。

4 ）前屈時の摇孔に関して, 正常群では, 一定の規則 性が文られ， stage を5つに分類した。患者群では， speed が同一でも，再現性がそしく，バラツキが大きか った。

\section{II-C-5. 椅坐からの起立動作分析一一筋電図 を中心に}

\section{岐阜大学整形外科}

西本 省三 松永 隆信 有本 勝彦 喜久生明男 藤本 俊雄 中田 孝 安藤 英樹 八木沢芳生 赤星 義彦

運動器疾患の動作学的病態把握に資するため, 椅坐か らの起立動作時の軀幹拉よび下肢各筋の活動について観 察検討した，対象は 14 歳加 73 歳の健常人で, 筋活動 は日本光電製 12 channel テレメーター筋電計ならびに 電磁オッシロを使用し，表面電極で記録した。

折りたたみ椅子からの起立動作は殿部が seat から離 れるのを境として第1 相，第 2 相に分けて観察した.

起立動作の筋活動様式は個人差が多く全例必ずしも同 一の形式をとらないが，45名中 30 名 $66.7 \%$ にみられ た一般的な活動形式を述べると，動作開始と共に腹直

5) Standing up Action from Sitting PositionElectromyographical Study.

S. Nishimoto, T. Matsunaga, K. Arimoto, A. Kikuike, T. Fujimoto, T. Nakata, H. Andoh, Y. Yagisawa, Y. Akahoshi : Department of Orthopaedic Surgery, Gifu University School of Medicine. 
筋, 脊柱起立筋, 内転筋群, 大腿直筋, 前脛骨筋が放電 を開始し，やや遅孔て外腹斜筋，さらに第 1 相の中期で 大殿筋, 中殿筋, 大腿二頭筋, 腓腹筋, 長腓骨筋が活動 を始める。

個々の筋の活動時期ならびに起立動作に预ける役割に ついて特徵的々思われる所見を要約すると，身幹筋では 脊柱起立筋が第 1 相・上体の前屈を制動しておうり, 殿筋 群では大殿筋が第 1 相で股関節の屈曲を制動し, 第 2 相 て股関節を積極的に伸展させる。一方大腿筋群のらち大 腿直管と大腿二頭筋は第 1 相後半で股・膫関節の stabilizer となり，第 2 相直前から大腿直筋は膝伸展，大 腿二頭筋は股関節伸展のため活動する。下腿筋群では前 脛骨筋が第 1 相で, 腓腹筋, 長腓骨筋は第 2 相で主に活 動する。

一方 60 歳以上の老人の筋活動は 50 歳台以下と異なり その特徴は筋放電時間が長いことで, 特に下腿筋群に顕 著であり動作中の体重心の動摇を制御するのに若年者よ り一層努力を要することを䚔わせた。

若年者あるいは老人のいずれにせよ立ち上がり動作の 主働筋となるのは大殿筋, 大腿直筋, Hamstrings であ り，他の筋は動作の遂行を support するために活動し ているものと思わ机る。

<質問>帝京大学り八部 岩倉 博光: 老年者の立ち 上がり動作が変化するのは, 訓練と教育によって若年者 のパターンに戻る可能性があるか.

<答>西本 省三: 教育すれば若年者と同梯の pattern を示し得ると思いますが，やはり限度があると考 えます，老人の pattern が大脳性のものか，末梢性の ものかとのことですが，明確には答えかねます、今後の 問題として追究して行きたいと思います。

<質問>長崎大整形外科 鈴木 良平: 立ち上がり動 作のときに左右の foot print をとって掠られるが，荷 重が左右いずれかに強くかかると見られる．利き足との 関係が何かありますか。

<答〉西本 省三: 利き足があるかぞうかについて明 確には答えられませんが, 前回中部整災学会で発表した 35 例について子市すと, 大半の例でどちらかの足に多 く荷重している傾向があり，その点から考光ますと利き 足があるものと思われます。

＜質問＞中伊豆りハビリセンター 䠌田 俊夫 : 52 年 の日本脳波筋電図学会に执いて, 片麻痺例の椅子からの 立ち上がり，坐る運動の動作解析を行った成績を報告し て和ります．大腿伸筋群の積分筋電波形のピーク值が， 健常人に比して, 立ち上がり時に遅机て, 生じる時には 早く出現するデータを得て倣りますが，先生の症例では 如何でしたか.
<答>西本 省三: 片麻瘏患者について我々は 2 例し か行って括りません. 向後の研究課題にして㧤ります.

\section{II-G-6. 下肢伸展時の股関節周辺筋の働き}

\author{
舞子台病院整形外科 岡田 勝 \\ 兵庫医科大学リハビリテーション部 \\ 藤原 誠 原田 義昭
}

下肢伸展動作機構について過去数回本学会にて発表し てきたが，今回下肢伸展時における股関節周辺筋の活動 樣相について筋電図学的検討を行った。

$<$ 方法 $>$ 健康成人男子 16 人の長内転筋，内側八ムス トリング, 大腿二頭筋, 大殿筋, 中殿筋, 大腿筋膜張筋 および大腿直筋について検討した，筋活動は Basmajian の fine wire 電極法で導出し, Medelec 社製筋電計に

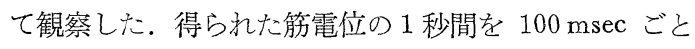
に三栄測器社製積分計を用いて積分, 積算した。被検者 を仰臥位にて肩，胸廓，骨盤部で固定し，各種下肢肢位 に和ける最大努力による下肢伸展時和よび一定努力によ る下肢伸展時の筋活動を測定した。 下肢肢位は膝関節角 度で表示した。

〈結果＞最大努力による下肢伸展時についてみると， 下肢伸展のいずれかの肢位で大きく関与している筋とし ては, 長内転筋, 大殿筋, 中殿筋, 大腿筋膜張筋おょび 大腿直筋があり，おのおのその筋の最大活動量比対する 比はそれぞれ平均，72\%，77\%，69\%，67\%，69\%であ った。 また少しあるいは匡とんど関与しない筋として は, 内側八ムストリングおよび大腿二頭筋があり, 前述 の比はそれぞれ 19\%，20\%であった，肢位の変化によ る筋活動の変化について見ると, 長内転筋および大殿筋 は下肢が屈曲位にあるほど大きな活動を示す，大腿直筋 および内側ハムストリングもほぼ同様の傾向を示す。逆 に大腿筋膜張筋は伸展位にあるほど大きな活動を示し, 大腿二頭筋もほぼ同様の傾向を示寸，中殿筋には一定の 活動様式は見出せない. 一定努力による下肢伸展時の活 動重は, 最大下肢伸展時の活動重に比すれば, 減少する が，活動パターンはほぼ同一の様相を示す。なお股関節 の肢位により,すなわち卧位と坐位の差により, 活動様 相を異にする筋もある。

＜質問＞長崎大整形外科 篠田 㑆: 積分計の時定 数について, われわれの教室では, 現在 $0.16 \mathrm{sec} て ゙$ 積

6) EMG of Hip Muscles in Propulsion.

M. Okada : Department of Orthopaedic Surgery, Maikodai Hospital.

M. Fujiwara, Y. Harada : Rehabilitation Center, Hyogo College of Medicine. 
分してますが，先生の方は，何秒でなさってますか，

<答>岡田 勝: 現在, 時定数は記憶しておりませ ん.

<答>岡田 勝（関東聥信病院の先生の質問に対し て) : (1) 膝関節 $30^{\circ} \sim 45^{\circ}$ といら肢位は, 屈曲位に大き く関与する筋群と, 伸展位に大きく関与する筋群の活動 の移行部にあり，全体の筋から久れば筋活量は少ない可 能性がある。（2)測定体位に関して，私共の行っている 下肢伸展動作は，閉鎖機構，即ち足部及び骨盤を固定し た機構内での運動であるので，重力はあまり関与しない と思わ机る。

\section{II-G-7. 膝関節障害における筋活動評価}

帝京大学リハビリテーション部 岩倉 博光 東京都老人総合研究所リハビリテーション医学部

$\begin{array}{llll}\text { 伊東 } & \text { 元 } & \text { 岩崎 } & \text { 富子 } \\ \text { 田中 } & \text { 繁 } & \text { 山田 } & \text { 道広 }\end{array}$

本研究の目的は膝関節機能を動作時の筋活動から評価 し，膝関節障害を種々の動作時筋活動をもとに再検討す ることにある.

方法は筋電計を用い, 大腿四頭筋と内側ハムストリン グスの活動を検索した．直筋，内外広筋は表面電極，中 間広筋のみワイヤー電極を用いた。同時に膝関節にエレ クトロ・ゴニオメーターを，足底にはフット・スイッチ を装着した。

10 名のコントロール群において, 歩行, ステップ昇 降, 階段昇降, 椅子からの立ち上がりとしゃがみ動作, 正座およびそれからの立ち上がりをしらべた。膝関節障 害者 5 名もほ涪同様の動作をくり返して評価した。

筋活動電位は整流平滑処理を行い，最大活動量はあら かじめ測定してこれを 100 とし，振幅波高を正規化して 比較した。

まず自由歩行においては大腿四頭筋が活動を示すのは 立脚初期に膝屈曲約 20 度を呈する 短期間のみで，他は ほとんど認められない。

次に骨折後の膝関節症, 軽度の 側方不安定を有する 65 歳男性例の 歩行では，まず各筋活動のばらつきが見 られ，また相対的に活動量が著しく大きい。

階段を昇る動作になるとこの特徴がより明らかで，膝

7) Muscle Activity in Knee Joint Dysfunction. H. Iwakura : Teikyo University School of Medicine, Department of Rehabilitation Medicine.

G. Itoh, T. Iwasaki, S. Tanaka, M. Yamada : Tokyo Metropolitan Institute for Gerontology, Dept. of Rehabilitation Medicine.
障害例の外側広筋, 中間広筋ではしばしば 100\%の筋活 動を要する、コントロール群に対し両脚荷重の時間が延 長して，この間に徐々に最大活動にまで上昇する。八 ストリングスにも $50 \%$ の筋活動を認める.

階段を降りる動作も同様の傾向があるが，通常の一足 一段法においては大腿四頭筋が二回の膝屈曲に合致した eccentric contraction を行っているため, 膝障害例で はこの筋運動コントロールが困難である．そのため二足 一段の方法をとるが大腿直筋よりもハムストリングスの 活動量が大きく, 荷重中心の位置る変化していると推測 された。

\section{II-C-8. 脳卒中片麻痺患者における下腿筋の 歩行筋電図}

山形大学整形外科

須田 昭男 渡辺 好博 茨木 邦夫 浜崎 允

脳卒中麻瘦に括ける足変形は, 下腿筋の反射的な異常 収縮による dynamic なものであり, 臥位では変形が消 失していても，起立や歩行などの特定の条件下で現われ るものが多い。このような足変形に対して，私達は積極 的に手術を行い，その成績については昨年の本学会で発 表した。今回は, ‘手術を施行した 22 例の腓腹筋，前脛 骨筋, 長腓骨筋について, 術前術後の表面電極による歩 行筋電図を行い検討したので報告する。

下腿筋の放電状態は，症例によって一定しないので， 主として遊脚期に放電を認める I 型, 遊脚期と着床期の 両期に放電を認める II 型, 主として着床期に放電を認 める III 型， いずれの phase でも放電を認めない IV 型 に分類した。

術前, 正常の放電パターン, 即ち, 前脛骨筋が I 型を 示し，腓腹筋と長腓骨筋が III 型を示したものは，術後 も正常の放電パターンを示した。

遊脚期と 着床期の 両期に 放電のみられたもので，術 後, 正常の放電パターンを示すようになったものが半数 以上あった。このように術後, 異常な放電が消失したの は, 手術により足変形が矯正され, 筋緊張のアンバラン スが改善されたためと推測される。

<質問＞神奈川リ八センター 安藤 徳彦 : (1)活動

8) Electromyogram at Walking of Leg Muscles of the Patients with Post-stroke Hemiplegics. A. Suda, Y. Watanabe, K. Ibaraki, M. Hamazaki : Department of Orthopedic Surgery, Yamagata University School of Medicine. 
放電型を分類なさって，その各型と患者の機能テスト上 の筋の分離性叔よび歩容とそれぞれ相関性があったか， 和教光下さい。(2) 外科手術後, 歩行時放電パターンの 改善がみられ，その理由は筋アンバランスの改善による と言われたが，それはアキレス腱延長，前脛骨筋移行の いずれにより大きく負うているか，技考光を拈教光下さ い.

＜答＞須田 昭男：(1) 共同運動については, 術前, 全例に flexion synergy がみられをした. 内反変形が中 等度以上のもので，前脛骨筋に随意性収縮を認めるもの や flexion synergy による前脛骨筋の収縮が著明なも のに対して，前脛骨筋の腱移行を行っております．今 後, 大腿部での表面電極による筋電図をも分析して, 共 同運動について検討して行きたい. (2)術後，内反変形は 全例で消失し，軽度の尖足を残したものが数例ありま す．尖足を残した例は，腓腹筋の緊張が強いためではな く，前脛骨筋の移行術後前脛骨筋の緊張が弱くなったた めと思います。移行した前脛骨筋とアキレス腱延長した 腓腹筋の緊張のバランスが問題ですので，足変形には両 筋とも関与すると思います。

\section{II-G-9．片麻痺にみられる粗動運動時の患側 より健側への Overflow について}

\author{
埼玉医大リハビリテーション科 \\ 三上 真弘 近藤 徹 \\ 東京都神経科学総合研究所 \\ 谷口礼二斉藤 宏 中村 隆一
}

脳卒中後片麻㾇に扎いて歩行時に健側下肢の筋活動が 患側のパターンに似て来ることは Hirschberg によって 述べられ，両下肢の運動が相互に影響を及ぼし合ってい ると考えられる．前回我々は連合反応により健側の運動 が患側に影響することを示した．今回は患側下肢より健 側下肢への管活動の放散について検討した。

対象は脳卒中後片麻舫患者 23 例（右片麻㾝 14 , 左片 麻痺 9 ) で，被検者をベッド上仰臥位とし，両下腿を心゙ ッドの端より下垂し，膝 $90^{\circ}$ 屈曲，足関節 $0^{\circ}$ となるよ らにした。両側の外側ハムストリング $(\mathrm{H})$ ，腿直筋 (Q)，前脛骨筋 (TA)，下腿三頭筋 $(G)$ ，健側前腕伸 筋群に表面電極を貼り付壮光刺激を合図に次の如き 3 つ

9) Overflow of the Phasic Movement in Patients with Hemiplegia.

M. Mikami, T. Kondo : Dept. of Rehabilitation, Saitama Medical School.

R. Taniguchi, H. Saito, R. Nakamura : Tokyo Metropolitan Institute of Neuroscience.
の運動を行わせ，その時の筋電四を記録してそれぞれの 反応時間を計測した。命じた運動は，（1）健側手の素 早い把握，（2）健側足関節の素早い背屈，（3）患側足 関節の素早い背屈, で各運動は素早く行いすぐ力を抜く ようにして tonic movement とならぬよらに注意し， それぞれ 20 回ずつ行わせた。

23 例中患側足関節背屈で健側 TA にも筋活動のみら れたものは 13 例ありこれらの症例について検討した。 手の把握は被検者の正常な反応時間と考兄られ，これと 健側足関節背屈運動時の健側 TA の反応時間を比較す るとほぼ同じで有意差がなかったが，健側運動時の健側 TA，患側運動時の患側 TA には有意の差があり，患側 の反応時間が遅くこれは麻瘏のためと思われる．患側運 動時の患側 TA と健側 TA (mirror movement) を比 較すると両者の反応時間には有意差がない。このことは mirror movement は患側の運動とほぼ同時に出現し, その発現は麻痺のため運動に多くの努力を必要としこの overflow が健側に 放散して出現することを示している と考えられる。一側下肢の随意運動時には対側下肢に対 し本来抑制がかかっているはずであるが，片麻痺ではこ の抑制が不十分となり，患側より健側の overflow を起 こし mirror movement が出現すると考える.

＜質問＞中伊豆リハビリセンター 等田 俊夫 : 歩行 動作時に患脚より健脚への overflow がどのようなパタ ーンとして観察されるかについて御教示下さい.

<答 >三上 真弘：連合反応はある動作を最大努力で 行らとき出現しその出現するパターンはその患者につい ては何をやらせても一定である．健側手に杖を持たせる 等の tonic motion が患側の連合反応を引き起こし歩行 の障害となることは十分考えられる.

<答 $>$ 三上 真弘（金沢大の 奈良先生の質問に対し て）:今回の報告は仰臥位での 足関節背屈運動時にみら れた mirror movementについて報告したもので，歩 行時の検査をしたわ防ではないが，このような現象が認 められるといらことは，健側を患側に合わせて歩かなく てもその筋活動に変化が起こることが考学られる。また 健側を患側に合わせて歩行してもその各 phase に見ら れる筋活動は swing phase には stance phase に活動す る筋の活動はみられないはずであるが，実際に swing phase に stance phase に活動すべき筋の活動がみられ ることは mirror movement が出現していると考えら れる. 


\section{II-G-10. 足 MP 関節の動き}

長崎大学整形外科

古田 千事 平野 英二 乗松 敏晴

千葉 剛次 林 拓男 藤田 雅章

松坂 誠応篠田㑆 富村 健

三村 寛 寺本 司 橙林 好隆

鈴木 良平

足 MP 関節に関する研究は，比較的少ないが，当教 室では，足 MP 関節の動き，足 MP 関節の動きと床 反力及び下腿外来筋の関係について述べてきた．今回 は，それにつ吅加えて，足 MP 関節の動きと，それに 関与する深在節の関係について報告する.

く方法＞我々が従来述べてきたスティックピクチャー カメラを用いての歩行解析に床反力と筋電図を同期記録 した，筋電図は，長拇趾伸筋，長趾伸筋，長趾屈笳，長 拇趾屈筋を記録し，記録には $70 \mu$ のコイルを用いて作 製した埋め込み針電極を用いた。足 MP 関節の動き は，第 5 趾側よりみた. 歩行周期は，ディクロッケの分 類に従った.

<結果 $>$ 足 MP 関節の 角変位は， IV 期後半より I 期にかけて大きな角変位を示した。筋電図において，長 拇趾伸筋は， IV 期を除いて筋活動がみられ， II 期に大 きな筋活動がみられた。長趾伸筋は，IV 期後半より III 期にかけて筋活動がみられたが，筋活動の大きさはほぼ 一定であった。長趾屈筋は，IV 期全般に 筋活動がみら れたが，その大きさは注淰一定であった。長拇趾屈筋 は，IV 期半ばより筋活動がみられ，I 期直前に大きな 筋活動を示して終了していた。

〈まとめ> (1) 足 MP 関節の角変位は，IV 期後 半より I 期にかけて大きな 角変位を示した。（2）長拇 趾伸筋及び長趾伸筋は， II 期に筋活動を示し， 足 MP 関節保持に関与していると思われた。（3）長拇趾屈筋 及び長趾屈筋は，IV 期に筋活動を示し，特に長拇趾屈 筋は，床反力との関係より，後脚けりだしに関与してい ると思われた。

10) The Movement of MP Joint of Foot. S. Furuta, E. Hirano, T. Norimatsu, G. Chiba, T. Hayashi, M. Fujita, N. Matsuzaka, T. Shinoda, K. Tomimura, H. Mimura, T. Teramoto, Y. Narabayashi, R. Suzuki : Department of Orthopedic Surgery, Nagasaki University School of Medicine.

\section{II-G-11．歩行速度による床反カ-カ線図の变 化}

国立療養所長崎病院整形外科 立野 泰 長崎大整形外科 松本 直昌 吉良 秀秋 宮田 定倫 楢林 好隆 鈴木 良平

<目的>歩行時の床反力の 2 分力を合成した「床反 力ー力線図」を作り「形」の解析を目ざしている．今回 は歩行速度が，この力線図にどのような影響を及洼すか 若干の検討を加えた。

<方法> (1) 床反力0 3 方向成分の らち 2 分力上りな るリサージュ波形を描き，これを力線図と称し，床反力 の矢状面への投影図を「 $\alpha$-力線図」，前額面への投影面 を「 $\beta$-力線図」，水平面への投影図を「 $\boldsymbol{\gamma}$ 一力線図」と名 付将た。（2) Cadence を一定にし，歩幅を変えた場合と 歩幅を一定にして Cadence を変えた場合，力線図がど のよらに変化するかを調べた。 (3) 垂直分力における第 1 峰 $\left(\mathrm{P}_{1}\right)$, 立脚中期の抜重効果の最大值 $\mathrm{V}$, 前後分力 飞持ける最大制動力, 最大推進力なぞから種々の指数を 導いて，形の変化に見合う parameter をさがした．(4) 対象は正常成人男子 6 名である。

<結果>(1) 垂直分力に和いて, 我々の実験では全て 第 1 峰 $\left(\mathrm{P}_{1}\right)$ が第 2 峰 $\left(\mathrm{P}_{2}\right)$ より大き $<$, Cadence, 歩 幅の増加につれその差が大きくなる．特に歩幅の増加の 場合差は著明となる。それとともに立脚中期の拔重効果 も歩幅, Cadence の増加とともに大きくなる。（2) 前後 分力は, 歩幅の増加につれ, 制動力, 推進力ともに著明 に増加する. Cadence によっても変化が認められるが 軽度である. (3) 以上のことから， $\alpha$-力線図の原形であ るハート型は歩幅, Cadence の変化とともに，ある程 度の規則性をもって変化することがわかった，各 parameter の検討から，これら変化の規則性が立証された。

11) The Variation of the Floor Reaction-Diagrams in Walking Speed.

Y. Tatsuno: Department of Orthopedic Surgery, National Sanatorium-Nagasaki Hospital.

N. Matsumoto, H. Kira, S. Miyata, Y. Narabayashi, R. Suzuki : Dept. of Orthopedic Surgery, Nagasaki University School of Medicine. 


\section{筋 電 図}

座長 日本大学整形外科 峯島 孝雄 慶応大リハビリテーションセンター 千野 直一

$$
\text { II-G-12 } 19
$$

\section{II-G-12. 整形外科領域における電気学的診 断について}

益田赤十字病院整形外科 福島 美歳

我々は最近 3 年間に行った約 300 例の筋電図及び神経 幹伝導速度について若干の知見を得たので報告する。

1) 腰椎疾患について一椎間板へルニア 11 例, 脊椎 不安定症 (degenerative spondylolisthesis を含光) 20 例, 椎間板変性症 (spinal canal stenosis) 38 例, その 他 169 例について行った。 異常所見は 62 例に認め, 107 例は正常であった。

筋電図上の特徵として, spinal canal stenosis に馬尾 神経損傷は両側性または一側性でも2つの根レベルの denervation を認めた。椎閒板へルニアについては, denervation potential を認めても必ずしも手術適応と はならない，また逆に筋電図上異常がほとんどないもの でも，ミエログラフィーを行い異常が発見され手術的治 療を要した。疼痛が消失した後も denervation はしば らくみられた。

2 ）末梢神経損傷について一完全損傷，不完全損傷ま たは neuroapraxia であるかを受傷後 3 週以後の筋電図 により診断し，手術の適応を決定できた。 36 例の神経 損傷のうち，上肢では尺骨，正中，及び橈骨神経，下肢 では坐骨及び腓骨神経が多かった，不完全損傷の場合ま たは圧迫による完全損傷は internal neurolysis を行っ ているが，明らかに有効と思われる症例もあった。

3 ) Entrapment neuropathy について一神経幹伝導 速度の遅延を示すものに対しては，ステロイド剤の局注 を2,3 回行い, 効果のないものに対しては手術的療法 を行い，神経はく離術も併用している. internal neurolysisにより症状は早期に改善されている.

4 ） その他, 多発性筋炎, motor neuron disease, peripheral neuropathy 特に糖尿病性が多い, 著明な一

12) Electrodiagnosis in Orthopedic Surgery. M. Fukushima : Division of Orthopedic Surgery, Masuda Red Cross Hospital.
側の下肢の筋萎縮にもかかわらず，筋電図上異常を示さ ず，血管性といらことが判明し，Leriche 症候群と診断 された。

以上 300 例について, 統計的観察と若干の治療上の知 見を報告した。

\section{II-C-13，上肢知覚神経伝導検査における 問 題点（第 2 報）}

慶応大学リハビリテーションセンター 木村 彰男 千野 直一

我々は，知覚神経伝導検查に扮ける問題点を明らかに するために，さまざまな方法で検査を行っているが，その 一部は第 8 回日本脳波・筋電図学会において報告した。 すなおち, 健康成人に拈ける手関節部での知覚神経伝導 検査に和いては, 正中神経では, 得られる Sensory Nerve Action Potential (SNAP) の amplitude の大 ささから，逆行性刺激を用いる方が好李しく，一方尺骨 神経の逆行性刺激では, SNAP への M 波の混入がみら れるため, 順行性刺激を用いる方が望ましい，という結 論を得た。 また，手関節部での overflowといらやっか いな現象についても言及した.

今回は更に，手関節部に加え肘関節部にても知覚神経 伝導検査を行い, 幾つかの興味ある知見を得た。

対象は，健康成人男子 11 名 20 肢で, これらの症例 の正中及び尺骨神経をそれぞれ，手関節部，时関節部 にて順行性と逆行性に刺激して検査を行った。 そして SNAP の amplitude と, 知覚神経伝導速度 (SNCV) を測定し，以下の結論を得た。

1）正中・尺骨神経共，前腕部での SNCV は，順行 性及び逆行性刺激により有意差はない.

2）尺骨神経の逆行性刺激では，时関節部においても M波の混入がみられるため, 順行性刺激を用いるのが 望ましい。

3）尺骨神経の順行性刺激により，肘関節部正中神経 で SNAP が記録できる症例があったが，こ机について は Martin-Gruber の anastomosis を中心に今後検討 を加えていく予定である。

（答〉木村 彰男（峯島先生の質問に対して）：Martin-Gruber anastomosis については, 手根管症候群に おいてこれを疑われている症例についての知覚神経伝導 検查を行ったり，あるいは，神経をブロックした状態で

13) Problems in the Sensory Nerve Conduction Study (The 2 nd Report).

A. Kimura, N. Chino: Rehabilitation Center, School of Medicine, Keio University. 
検査を行って検討したいと考兄ている.

<答 $>$ 木村 彰男 (日大, 佐藤先生の質問に対乙 て) : (1) 手関節部での電流の overflow は, supramaximum の刺激, 特に supramaximumを $20 \%$ 位超えた刺 激で起こりやすかった。 (2) 現在のように, 微小な amplitude まで測定できるよらになってきた場合には， SNAP の amplitude も有力な $1 つ の$ 示標として考光る ことができる，それ故，正中神経では，より大きな amplitude を得られる逆行性刺激を用いる方が良い，と 考えている.

\section{II-G-14. 誘発脊䯣電位の 実験的研究及び弇 䯣損傷患者への臨床応用}

金沢大学医療短期大学部 立野 勝彦 馬場 久敏 金沢大学附属病院 湯上博

Rancho Los Amigos Hospital Paplo Valencia, Laulence McKinley

検査をするにあたっては, 容易で安全かつ正確さを持 たねばならないことは言うまでもないが，我々は末梢神 経刺激により脊椎棘突起から導出することを試みた。成 猫をもちい，坐骨神経に 刺激電極を置き， 1 秒間に 10 回の単相性の刺激を加兄た。記録電極は脊椎棘突起に K-wireを挿入した。このシグナルには, Medelec M 86, 刺激装置 SC-6, 加算装置 DAV-6・2 台，増幅 器 A-6・2 台で試みた。棘突起で得られた波形は, 末 梢神経を刺激し硬膜外で得られた波形と大差なく, 明瞭 に 3 相性の山がみられたが, 刺激電圧は硬膜外でのもの が低電圧で得られた．刺激電圧の違い及び記録電極の位 置により波形は異なっていた，脊䯣後索部を切離する実 験では，今井らの硬膜外と同様， $\mathrm{N}_{2}$ の波形が消失し， また側索切離すると $\mathrm{N}_{1}$ の波形が 消失するのが認めら れた。このことから， $\mathrm{N}_{1}$ は側索， $\mathrm{N}_{2}$ は後索に由来する ものと想定された，脊䯣に distraction をか仔，阻血の 実験を試みると， $15 \mathrm{~mm}$ の distraction では，可逆性 の変化， $20 \mathrm{~mm}$ の distraction では，時間の経過とと 己に不可逆性の変化, $30 \mathrm{~mm}$ では distraction 直後よ

14) The Spinal Evoked Potentials Conducted from the Spinous Processes.

K. Tachino, H. Baba : Junior College of Allied Health Professions Kanazawa University.

H. Yugami : Kanazawa Medical University.

P. Valencia, L. McKinley: Rancho Los Amigos Hospital.
り不可逆性の変化をみた。また血圧の低下による実験で も形波の変化をみた。脊骾損傷患者一の臨床応用とし

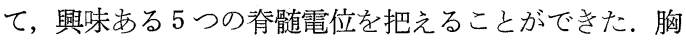
腰椎部の脱臼骨折の不全損傷例で， Harrington rod で 矯正した際，脊髄電位の消失をみ，緩解すると元波形に 復帰した。 $\mathrm{C}_{4}$ の不全損傷例では明膫な波形を見出し， $\mathrm{C}_{6}$ の不全損傷例でも小さな波形を認めた. $\mathrm{C}_{5}$ の完全損 傷例と思われた症例で微小ながらも波形を見出し，わず かな知覚の回復をみた。 $\mathrm{C}_{5}$ の完全損傷例では, 全く波形 を記録することはできなかった，以上より棘突起での導 出は脊髄電位を示し，臨床面では，手術中の警告にな り，また完全損傷と不全損傷との判別になるであろう. ただ春髄電位が春髄の何を把学ているのかは，今後の大 きな課題となっている。

<質問＞京都市立病院内科 瀬古 敬 : 次の点につ いて御教示いただきたい. (1) 加算回数を何回としたか. (2) Time Constant をどのように設定したか(HF，LF). (3) 坐骨神経刺激でみた場合頸髄レベルでも有意の導出 波形が得られるかどらか.

<答>立野 勝彦：(1) 加算回数 $50 \sim 100$ で行 5. (2) $50 \sim 100 \mathrm{~Hz}$ の刺激頻度, 単相性のものを使う. (3) 頸椎 部であると坐骨神経からは算出できず，尺骨神経を利用 する。

\section{II-G-15．再現可能なランダム刺激による 体 性感覚誘 発電位と聴覚誘発電 位—bio-feedback に関連して}

神奈川県総合リハビリテーションセンター七沢病院 福井 图彦 丹澤 章八

昨年度の規則波刺激による 体性知覚誘発電位 (SER) および聴覚誘発電位（AER）の報告に続いて今回はラ ンダム刺激を用い，乙かも再現可能であるような方法を 考案し，昨年同様 SER と AER の協調，相関性の検 討を行った。

まず，幅 $1 \mathrm{~ms}$ の矩形波発生装置を作製し，その発生 操作は manual control が可能なように設計する。こ れを用いて得られたランダム波を磁気テープに記録して おき，いらもこれにトリガーさせて刺激装置が働くよう にしておけば，ランダム刺激による SER が得られる

15) Somatosensory Evoked Response and Auditory Evoked Response by Reproducible Random Stimulation-Related with Bio-Feedback.

K. Fukui, S. Tanzawa : Kanagawa Rehabilitation Center, Nanasawa Hospital. 
し，またそのまま増幅してへッドフォンにつなげば， SER の刺激と同期したランダムな音刺激を与えること が可能である。

磁気テープを最初からスタートさせ，加算回数さ光同 じにして打けば, ランダムとはい方, 総体的には同量, 同質の刺激を再現できるので，ある操作の前後で SER， AER の変化を追及する場合に好都合である.

片麻痺の正中神経のランダム刺激による SER を調 べると, 臨床的にみられる知覚障害の程度を上回る変化 が SER に現われ, 重いものでは SER 曲線の平坦化, 中等度障害では振幅の減少, 潜時の遅れ， $\mathrm{P}$ 波 $\mathrm{N}$ 波な ぞの変形, 軽度あるい瀶床的に知覚障害がないと思わ れる例では潜時の遅れがみられる。

しかし，正中神経刺激と 同期した聴覚刺激を与兄る と, 患側つ遅延している潜時には明らかに短縮がみられ るが, 健側は不変か, 僅か短縮するか，ときには延長す ることもあり不定であるが，いずれにしても健・患側の 差は短縮する。

また，正中神経刺激と聴覚刺激を同期して与えて得ら れるレスポンスは，単独得られた SER と AERを 紙上で合成したものと比較すると患側では前者の $\mathrm{P}_{3}$, $\mathrm{N}_{3}$ の潜時が短縮しているのにたいし，健側では変化が なく, 患側では両刺激の加重により, 新しい回路が開く ものと考光られ，聴覚的 bio-feedback の理論的根拠 の一つになるであろう.

\section{II-C-16. 頸椎症性脊䯣症における 痤性麻痺 の $\mathrm{H}$ 波による評価と問題点}

兵庫県リハビリテーションセンター 南 久雄 神戸大整形外科 武部 恭一 片岡 治

頸椎症性脊髄症により, 下肢頸性麻痺を呈する症例に 対して我々は，下肢誘発筋電図に打ける $\mathrm{H}$ 波を指標之 した $\mathrm{H}$ 反射頻度抑制曲線を用いて，痓性の程度を観察 的汇とらえる試みを行って来ている。 しかし，下肢痓性 麻痐を呈するにもかかわらず， $\mathrm{H}$ 波の出現しない症例 や， M 波が先行し $\mathrm{H}$ 波が出現しにくい症例が散見され る. 今回, その原因について検討を行った。

<症例＞頸髄，胸髄レベルの春髄障害により下肢痓性 麻盘を来した患者， 66 症例に施行，このうち 13 例にお

16) Analysis of the Spastic Paralysis by the Evoked Electromyogram.

H. Minami : Hyogo Rehabilitation Center.

K. Takebe, O. Kataoka : Department of Orthopedic Surgery, Kobe University School of Medicine.
いて $\mathrm{H}$ 波が検出されなかった。ささらに脛椎部に障害が ある腰椎椎間板へルニア症例 6 例にも施行した。

く結果> H 波が検出されなかった症例について検討 すると, 腰椎部に病変が合併していた症例が 6 例に見ら れた. 合併症としては, 腰部脊椎管椎狭窄症, 腰部後縦 靱帯骨化症等が見られた。

次に腰椎椎間板ヘルニア症例について検討する. 左側 $\mathrm{L}_{5}-\mathrm{S}_{1}$ の腰椎推間板へルニア例は, 患側においては, $\mathrm{H}$ 波は検出されなかった。健側においては，正常のパター ンの $\mathrm{H}$ 波が検出された。腰椎部に病変が 偏側性に存在 する場合は，健側のみ $\mathrm{H}$ 波が検出される.

<まとめ>1) 腰椎部に腰部脊椎管狭窄症, 後縦鞄帯 骨化症， $\mathrm{S}_{1}$ 神経根障害がある症例においては，H 波が 検出されないか，または， M 波が先行し，微弱な $\mathrm{H}$ 波 しか検出されない。

2 ）莖頁椎症性脊髄症により下肢病性麻瘦を来す症例に おいて, 腰椎部に, 腰部脊喵迶管狭窄症, $\mathrm{S}_{1}$ 神経根障害 等を合併する場合は， $\mathrm{H}$ 波による検索は困難であり， 頻度抑制曲線による痓性の分析は適さないものと考え る.

3 ) 頸椎症性脊髄症に打いて, 臨床的に下肢痤性麻痺 を来している症例で， $\mathrm{H}$ 波が検出されない場合は，腰 椎部の精查を行なら必要性があると考える.

<質問>登別厚生年金病院 大島 峻：痓性の測定 の目的で $\mathrm{H}$ 波回復曲線を得る場合, 10 回連続すると高 周波数領域で $\mathrm{H}$ 波のとぎれ等が見られることがあり， $\mathrm{H}_{2} / \mathrm{H}_{1}$ Ratio の方が臨床所見と一致し易いと思われる. 演者は, 特に高周波数刺激領域で, $\mathrm{H}$ 波の 周期的変化 や欠如を認めなかっただろらか.

<答>南 久雄: (1) 連続刺激にて H 波の消失と出 現の反復は見られなかった。 (2) $\mathrm{H}_{1} / \mathrm{H}_{2}$ 比を見るよりも 反復誘発筋電図の方が春髄機能をより良く反映している ものと考える．末た，臨床所見とも良く一致している.

<追加>千葉大神経内科 渡辺 誠介：正常人で表面 電極で $\mathrm{M}$ 波 $\mathrm{H}$ 波が 同時に出現するような刺激をあた え, 表面電極の活性基準電極のすぐとばに単一筋線維電 極を直角に刺入すると，深さを変えながらいくらかの神 経筋単位を算出することがでさる，その結果表面電極の $\mathrm{M}$ 波に一致するもの， $\mathrm{H}$ 波のところにのみ出現するも ののほか， $\mathrm{M}$ 波にも $\mathrm{H}$ 波にも出現するものがみられ た.このことは正常人の 表面電極による $\mathrm{H}$ 波の中には $\mathrm{F}$ 波がかくされていることがあることを意味している. 南先生の 症例も F 波であった可能性もあるのではない か.

<質問＞岡山大学整形外科 長島 弘明：遂行性に anterior horn cell を firing させる control delay time 
を $1 \mathrm{~ms}$ とするその值は適当と思われますか.

\section{II-C-17. パーキンソン病における 補助呼吸 筋の動作筋電図学的検討}

水俣市立湯之児病院リハビリテーションセンター

森本 敬三 山本 正昭
高橋修一朗 山永 裕明
産業医大リハビリ医学科 浅山 滉

きリハビリテーションの立場から本疾病を考える際に最 も大きな問題の 1 つに, 呼吸機能の獲得や維持に限界が あることである，そこで我々は本疾病における補助呼吸 筋の表面筋電図, 肺気量分画及び歪曲線を同時に測定 し，いくつかの知見を得たのでここに報告する.

<方法>協力の得られたパーキンソン病患者 9 名及び 対照者に健康成年男子 2 名の計 11 名に 対して下記の如 く検査した。筋電図検查筋は坐位に扣ける胸鎖乳突筋, 斜角筋群, 大胸筋, 前鋸筋, 外腹斜筋, 広背筋それに上下 僧帽筋の 8 筋を対象として, 肺機能はスパイログラフに より 1 秒率 (Tiffeneau 式), \% VC (Baldwin 式), $\% \mathrm{MZZ}$ (Baldwin 式) 等を測定した。同時に動歪測定 器を利用してペーパーストレンゲージによる胸郭の呼吸 時にお攷る動きを測定した。

<結果 $>1$. 筋電网所見：(a)安静時及び肺活量測定 時，健常者に比べ常時放電例が多かった（b) 最大換気 時, 健常者はリズミカルな筋放電を示すのに対し, 常時 放電例が多かった。 2 . 肺気量分画所見： 1 秒率 $56.3 \pm$ 23.7 と低值を，\%VC は $85.9 \pm 19.6$ と正常範囲， $\% \mathrm{MVV}$ は $46.4 \pm 14.7$ と低值を示した。これらの值と 臨床的重症度（Yahr と ADLの stage）との順位相関 ではすべて有意の差を認めなかった。 3. 歪曲線所見 : $5 \sim 6 \mathrm{c} / \mathrm{s}$ の微小波形の出現が認められた.

以上の $\mathrm{EMG}$ 所見より本疾病では呼吸気ともに常時 放電を示す例が多く, 呼吸補助筋としてリズミカルな動 きすなわちスムーズな chest expansion に欠流てい るし，また歪曲線での $5 \sim 6 \mathrm{c} / \mathrm{s}$ の微小波形の出現は， 通常本疾病の上肢の resting tremor の周期は $4 \sim 6 \mathrm{c} / \mathrm{s}$ といわれており，それと極めて近似した周期であり，

17) Electromyographical Study of Accessory Respiratory Muscles on Patients with Parkinson's Disease.

K. Morimoto, M. Yamamoto, S. Takahashi, H. Yamanaga : Yunoko-Byoin Rehabilitation Center, Minamata Municipal Hospital.

K. Asayama : Department of Rehabilitation, University of Occupational Environmental Health.
EMG 所見と合わせて呼吸補助筋にもパーキンソン病特 有な tremor 様変化があるものと充分示唆される所見で あった。 また臨床的症状に比して呼吸機能状態が悪い例 が多く, 本疾病を管理する我々にとって苦慮する問題点 である。

\section{II-C-18. 甲状腺機能立進症の筋電 図 検 討 （第 2 報）}

\author{
川崎医大りハビリテーション科 \\ 長尾 史博 土肥 信之 日野 洋介 \\ 長谷川寿美玲 明石 謙
}

Hyperthyroidism（バセドウ氏病）には種々の程度の 筋障害を伴らことは，1895 年 Buthurst が発表以来多 数の報告がある. 事実, 脱力や“やせ”のものが強く, その原因が不明のまま長く放置されている症例もある. 今回我々は Hyperthyroid myopathy の筋電図所見に ついて，検討を加えたので報告する．当院で加療してい る Hyperthyroidism の患者の筋電困を記録, 同時に波 形分析を行った．波形分析は周波数分析と積分值を用い た．筋障害の程度を定量化するため，周波数分析ヒス下 グラムを高周波成分の混入と低周波成分の程度により段 階に分け, 正常人の前脛骨筋の波形積分值 $(41.7 \pm 26.7$ $\mu \mathrm{Vsec} / 180 \mathrm{msec}$ ) 平均標準偏差值外に 低下したものは, 低電位が著明であるためミオパチ一の程度が 1 段階強い ものと判定した，筋電図は治療開始前，血中ホルモンが 正常化 (euthyroid) した状態, 術前, 術後の一定期間 の検查を行い, それぞれミオパチーを筋電図所見より高 度 (Advanced), 中等度 (Moderate), 軽度または正 常 (Slight or Normal) の 3 段階に分類した。被検筋 としては前脛骨筋を用いた。

症例数, 男女比, 筋の脱力や萎縮を示守頻度は表のご とくである，筋電図異常は 37 例 $(67 \%)$ にられた。 筋の症状と筋電図異常との関連もみられるが，年齢的要 素も強く, 30 歳以上では関連が深い。血中ホルモンと の関連は少ない. 血中ホルモンが正常になっても筋電図 所見は異常のままのことが多い. 抗甲状腺剤の内服治療 開始後の期間とミオパチー程度との関連もみられない. 外科的治療例では筋電四異常の改善は比較的すみやか で，8週以後は正常または軽度異常を示すのみである. 甲状腺ミオパチーの本態は明らかではないが, 病理学

18) Electrophysiological Evaluation of Hyperthyroid Myopathy.

F. Nagao, N. Dohi, Y. Hino, S. Hasegawa, K. Akashi : Department of Rehabilitation, Kawasaki Medical School. 
的変化は約 $20 \%$ にしかみられないという点を考えれば, 生化学的変化によるものであり, 治療に上る回復も速や かであるらと考兄られる．ミオパチーを定量化し経過を 追って調べた報告は, 私達の知る限りでは初めてである.

<質問〉慶応大リ八ビリテーションセンター 千野

直一: Myopathy の筋電図学的判定は, 波形分析にて 行われておられるようですが, その再現性, 各筋の S.D. なぞ統計学的に有意な判断が下せるものですか.

<答>明石 謙：(1) 波の所見で異常を認める場合 「異常」そ判定し，それを周波数分布と積分值によって 分類した。ただ千野先生の御指摘通り積分值にはバラツ キは大きいようである. (2) 正常と判定する場合少なく とも 5 力所に針電極を挿入し異常所見を認めない場合に 正常之した。

\section{II-G-19. Spasticity と上肢 $\mathrm{F}$ 波について}

\author{
日大整形外科 町田 正文 \\ 菅原 吉隆 岡田 章 鳥居 孝昭 \\ 浅井 享 峯島 孝雄 佐藤 勤也
}

末梢神経刺激により誘発される $\mathrm{F}$ 波は，すでに 1950 年 Magladery により報告されている。しかし，その 後 F 波の生理学的研究はいくつかみられるが, 臨床応 用については，神経伝導速度の測定に利用されるにすぎ ない。

今回われわれは, Hemiplegia 10 例之 Cervical Myelopathy 20 例の比較的 Spasticity の強い症例飞導出 される $\mathrm{F}$ 波と正常人 50 例の $\mathrm{F}$ 波を比較検討した.

その結果, 正常人の $\mathrm{F}$ 波の出現率は約 $30 \%$ 前後で, 神経伝導速度は, 手関節部刺激では $58.5 \pm 2.3 \mathrm{~m} / \mathrm{sec}$, 肘関節部刺激では $60.9 \pm 3.0 \mathrm{~m} / \mathrm{sec}$ であり，振幅は 50 300 $\mu \mathrm{V}$ であった. Cervical Myelopathy では, $\mathrm{H}$ 波之同様に 出現頻度の増加, 振幅の増大傾向が 認め られた。このことは， $r$ 系の活動性に比例するとされて いる $\mathrm{H}$ 波と， $\alpha$ 系の興奮性を反映する $\mathrm{F}$ 波が，ともに 脊㵦前角細胞の興奮準位を表わすものと思われた。

また, Hemiplegia では, 出現頻度は増加傾向にあっ たが，患側に抢ける F 波の振幅は一定の傾向を認める ことなく, F 波の伝導速度は約半数の症例比いて, 患側のみ軽度の低下が認められた。これには，いろいろ な要因が考えられるが, transsynaptic neuronal degene-

19) F-Wave in Spasticity.

M.Machida. Y. Sugawara, A. Okada, T.

Torii, T Asai, T. Mineshima, K. Satoh : Dept. of Orthopedic Surgery, Nihon Univ. School of Med. ration も一因と思われる. 今後症例数を増やし，検討 していきたいと思います。

<質問>慶応大リハビリテーションセンター 千野 直一：痤性患者の小手筋の $\mathrm{F}$-波栓菜において, $150 \mathrm{Vol}$ 以上の刺激をあたえた場合に amplitude の decrement が生じ，H一波と見末らがえることもあり得京すか。

<答〉鳥居 孝昭: $150 \mathrm{~V}$ の最大上刺激で， $\mathrm{F}$ 波を 測定し，更に刺激強度を増しても $\mathrm{F}$ 波の減少を認めな いことを確認しております。

く答〉町田 正文：central delay の $1 \mathrm{msec} に つ$ いて：Renshow がネコを用いて，前角細胞の self excitation には $1 \mathrm{msec}$ を要することを証明している。

\section{神経・筋}

座長 東北大鳴子分院整形外科 中村 隆一

$$
\text { II-C- } 20 \sim 28
$$

\section{II-G-20. Duchenne 型筋ジストロフィー症 保因者における 血清酵素学的検討}

国立療養所東埼玉病院 石原 伝幸 并上満

性染色体劣性遺伝の疾患である Duchenne 型筋ジス トロフィー症（DMD）に対する有効な治療法を持たぬ 現在, 予防措置として妊娠保因者の羊水検查による男児 の人工流産が行われてきたが最近は胎盤より採血し患児 を同定し選択的人工流産が可能な段階となり保因者の同 定は更に重要となった。保因者検出には一般に血清 CPK 検查が行われているがその検出率は70\%といわ れている. 我々は当院で経過観察中の DMD 児の母未 たは姉妹 70 名の血清酵素測定を行ったので報告する.

(1) Definite Carrier 6 名, 平均年齢 35.6 歳, CPK 平均 $164 \mathrm{U}, \mathrm{LDH}$ 平均 $375 \mathrm{U}, \mathrm{GOT} 28 \mathrm{U}$.

(2) Probable Carrier 8 名, 年蹂 36.7 歳, CPK 146 U, LDH $317 \mathrm{U}$, GOT $21 \mathrm{U}$.

(3) Possible Carrier 56 名, 年齢 38.9 歳, CPK $86 \mathrm{U}$, LDH $275 \mathrm{U}$, GOT $19 \mathrm{U}$.

(4) Definite Carrier で CPK が異常高值をとる例は

20) Serum Enzyme Study in Carriers of Duchenne Muscular Dystrophy.

T. Ishihara, M. Inoue : National HigashiSaitama Hospital. 
4 名で $67 \%$ となった． LDH が異常高值の例は 33\%, GOT では 1 例のみであった。

現在までに Carrier Detection の方法は血清酵素学的 方法として, GPT, Aldolase, HBD などの測定が推賞 されているが確認はされていない。 また LDH アイソ ザイム測定の有用性は最近否定された。他に筋力テス 卜, $\mathrm{EKG}$, 定量 $\mathrm{EMG}$, 筋生検, 生検筋の蛋白合成, 体内 $\mathrm{K}$ 測定，赤血球形態異常，赤血球膜燐酸化をみる 方法などが報告され CPKの検出率を越そらという試 みがなされてはいるが成功していない.今回 Definite Carrier 検出率 $67 \%$ は従来の報告によく一致した值で ある. 今後は残り $33 \%$ の検出に血清酵素の検討, ミ才 グロビンの検討などが有用かどうかを報告する予定であ る.

<質問>東北大鳴子分院 中村 隆一：(1) LDH, GOTをとくに検索した意味は何でしょらか。（2)母親 以外には検索がされているか.

<答 >石原 伝幸 : (1) 今回 CPK の測定值は一般の 報告を確認したに過ぎませんが，次回は m-GOT と Myoglobin の測定結果を発表する予定です。（2)患者の 母と姉妹で測定しただけで，父や兄弟については調查し て抢りません。

\section{II-G-21．筋ジストロフィー症児（者）の猆 柱水平面形状の経時的変化}

国立療養所下志津病院整形外科 斎藤篤 東京農工大保健体育 服部 恒明

Duchenne 型進行性筋萎縮症児（者）の脊柱変形の 予防対策を検討する目的で，坐位脊柱 X 線像をもとに した 2 年間の経時的変化について追跡調查を行った。省 柱の前後彎については,「過伸展型」「伸展型」「垂直型」 「屈曲型」「過屈曲型」の五群に，水平面形状として多い ものから「らせん型」（時計方向と逆時計方向）「直線 型」「不定型」の順に三群に分類した。 これらの各パタ ーンでの追跡調查では 50 例中 $26 \%$ は前後方向へ， $28 \%$ は側方へ，30\%は前後扣よび側方へ，残りの $16 \%$ が春 柱変形の増悪のほとんどみられない群にわけられた。

21) Studies on Spinal Deformity of Progressive Muscular Dystrophy.

A. Saito : National Sanatorium ShimoshizuByoin, Department of Orthopedics and Rehabilitation.

K. Hattori : Tokyo Agriculture and Technology College, Department of Health and Physical Education.
側面観での変化は, 過屈曲型で 10 例中 2 例は屈曲型 に改善し, 屈曲型では 17 例中 4 例は過屈曲型, 5 例は 垂直型，伸展および過伸展型には各々 2 例ずつと，特に 屈曲型での変化の多様性がみられた。. 垂直型 14 例中の 4 例は屈曲型へ移行し, 過伸展型 7 例中 2 例は伸展型へ 改善を示した。

次に椎体定点の $\mathrm{X}-\mathrm{Y}-\mathrm{Z}$ 軸上の投射から $\mathrm{X}$ 軸上の変 化を側彎比 (scoliotic ratio), $\mathrm{Y}$ 軸上の変化を後彎比 (kyphotic ratio), $\mathrm{X}-\mathrm{Y}$ 面上の変化を水平面屈曲比 (horizontal curviform ratio) と各々命名した。この らち側彎比についてみると $0<5.0$ では 5 例中 4 例は $<10.0$ に変化し， $5.0<9.0$ では 22 例中 12 例が比の増 大を示す. $10.0<15.0$ では 17 例中 8 例が増悪し， 4 例 が改善を示した。

以上の症例のらち定期的装具装着による起立訓練を行 ったものを含む A 群 $(\mathrm{N}=36)$ と起立を行っていない $\mathrm{B}$ 群 $(\mathrm{N}=14)$ について側彎比の変化をみると, A 群 $11.2 \pm 6.85$ から $13.8 \pm 7.88, \mathrm{~B}$ 群 $9.1 \pm 4.19$ から 14.7 \pm 8.46 と変化の増加がみられた。 これは後彎比 $\mathrm{A}$ 群の $18.1 \pm 8.25$ から $20.3 \pm 9.72$ ， B 群 $20.2 \pm 5.83$ から $20.7 \pm 7.15$ に比べ装具起立は後彎よりも䝮彎変形予防 に有効性を示唆した。 以上より多様な変形に対するきめ こまかな生活指導をその予防に強調したい。

<啠問>東北大鳴子分院 中村 隆一：年齢要因につ いてわかっていれば，和教え下さい。

<答 $>$ 斎藤 篤: 年齢と脊柱変形に関しては第14回 本学会で「屈曲型」変形を示すと述べ，2 年間の経過で は屈曲型および垂直型に変化が多様性を示していること を述べた。

\section{II-C-22. 進行性筋ジストロフィーの宜柱変 形，特に 側彎とその 対策について}

徳島大整形外科 松家 豊
井形 高明 山本 博司 片岡 正春

進行性筋ジストロフィー, デュシャンヌ型における答 柱側彎の経時的変化とその対策について報告する.

対象は国立徳島療養所の患者 33 名で, 昭和 45 年以来 3 年 2 カ月〜 8 年 9 カ月, 平均 6 年 8 カ月にわたり脊柱

22) Spinal Deformity of Patients with Progressive Muscular Dystrophy and its Treatment.

Y. Matsuka, T. Ikata, H. Yamamoto, M. Kataoka : Department of Orthopaedic Surgery, School of Medicine, Tokushima University. 
レ線を中心に観察した。脊柱側彎はその進行様相から進 行群と非進行群の 2 群に分けた。前者は 12 例で $20^{\circ}$ 以 上の側彎進行を示した。後者は 12 例で $20^{\circ}$ 以下を示し ほとんど進行がなかった。

進行群のらちでは急速な進行とゆるい進行を示すグル ープがある. 特に急速な進行グループは 12,13 歳頃に 進行が始まり 14 歳ではピークに達し, 側彎は $80^{\circ}$ 以上 の典型的な Collaps spine である.この歩行不能とな った年齢は平均 9 歳 4 力月で全体の平均 11 歳 10 力月よ り早く, また, 後彎を示す者が多い, 現存を含めた生存 年齢は最高が 19 歳で短命といえる. 非進行群では最高 19 歳 5 力月まで追跡したが一般に $15 ， 16$ 歳までは $10^{\circ}$ 以下でその後も進行は注とんどみら扎い。この歩行不 能となった年齢は平均 13 歳 1 力月で進行群に比べて長 く歩行能力を維持していた。をた，前彎や垂直の脊柱を 示す者が多かった.

かかる側彎の進行様相からみてその対策は予防を主体 とした歩行中心の機能訓練, 装具の導入など早期対策を もって非進行群にみちびくことが肝要である. 装具療法 として歩行用下肢装具では特に装具歩行後期において適 正な装具と脊柱変形発生をチェックしなければならな い. なた，身區幹装具は変形の形態や程度，残存筋力によ ってそれぞれ工夫が必要であり, 患者に負担の少ない簡 便なものが要求される. 現在試作使用中の軀幹装具の 2, 3について紹介する. 早期で軽度の場合には能動的 矯正法が考えられる. 変形の予防あるいは高度の変形に 対しては装具は坐位姿勢の保持のみを目的としている. また，装具歩行不能となった者にはすすんで軀幹コルセ ット付の長下肢起立装具を用いている.

<質問>愛知県心身障害者コロニ一 村地 俊二 (II-C-20, 21 に対して)：PMD 春柱側彎の症例の laterality (側彎凸側) に特徴的な所見はありましたか。 そしてその凸側に関与する因子にはどんなるのが考えら れるでしょらか。

く答〉斎藤 篤: 利き手について, laterality は左 利きでは 15 例中 1 例をのぞき左凸，右利きではほぼ右 凸が $2 / 3$, 左凸 $1 / 3$ であった. 約 30 例中利き足や足関節 の拘縮など他の因子についても検討の必要を考えます。

<答>松家 豊: laterality の要因としては筋力低 下のほかに ADL 上の姿勢の問題，関節拘縮や筋力の 左右差などの関与が考えられる. 右凸が統計上は多いが 必ずしも決定的とはいえない，右凸の多い理由として右 手利さ, ADL の姿勢の問題が考它られる.

<質問>川崎医大リ八科 明石 謙 : 非進行群と進 行群に分けて扰られますが，これは筋ジストロフィーの 進行度とは関係がないのでしょらか。
<答>松家 豊 : 非進行群のタイプは前彎や垂直の 脊柱を示するのが多く, 歩行能力も長く維持されている のでその対策として非進行群のタイプになるよう指導し てゆくことがのぞましい.しかし，デュシャンヌ型でも 筋力低下の抢そいものもある。

<質問 $>$ 愛知県心身障害者コロ $=$ 篠田 達明: 側 彎矯正用の補装具, とくに重度の子どものためのコルセ ットを興味深く拝見しました，重症心身障害児の脊柱側 彎にも応用できたらと思いますが，介護者の扱い易さ， 排尿排便などの際はどうするか，あるいは裖創などの問 題はいかでがしょらか.

<答>松家豊：坐位用装具は躯幹部と大腿部をね じによってとりはずし車椅子には軀幹部のみをつけて使 用することができる. 介助及び移動には特に取扱いやす く簡便にしてあり問題は少ない、裖創等の起こることは ない.

\section{II-G-23. Duchenne 型筋ジストロフィー症 巟の知能特性}

国立療養所箱根病院 岡崎隆 三宅 孝子 村上 慶郎 久保 義信 国立療養所東埼玉病院 石原 伝幸 井上 満

<目的 $>$ Duchenne 型筋ジストロフィー症児の WISC 検査結果に执いて, PIQ > VIQ の discrepancy が従来 興味ある問題として報告されている. 今回我々はこの問 題について言語発達の側面から検討を加えた。

$<$ 方法 $>$ DMD 坚 24 例 ( 8 歳 11 歳) に対L, WISC 及び ITPA 言語学習能力診断検査を実施.

<結果及び考察>WISC 検対結果より FIQ 74.3, VIQ 70.8, PIQ 83.3 (mean) が得られた。 また 24 例中 12 例に VIQ $>$ PIQ (15 以上) の discrepancy が 認められた。被験児を動作性優位の discrepancy 群（D 群) 15 例之 non-discrepancy 群（ND 群） 9 例の 2 群 に分け, WISC 及び ITPA 検査結果に検討を加えた. ITPA 全検査 PLA には 2 群間に差は認められず, 全 体的な言語発達水準は discrepancy の要因としては関 与していないと考えられる. WISC 及び ITPA の subtest 結果では, その profile には 2 群間に差は認められ

23) Intellectual Function in Duchenne Muscular Dystrophy.

T. Okazaki, T. Miyake, K. Murakami, Y. Kubo: Hakone National Hospital.

T. Ishihara, M. Inoue : Higashi-Saitama National Hospital. 
ずまたその level においては 11 subtest で D 群が低 值を示し逆泟り 11 subtest では高值を示した。この profile の同一性より, discrepancy の要因は各々の 11 subtest に共通して関与している因子の違いにあると考 えられる. 二群間で D 群が低值であった 11 subtest に 共通する因子は課題反応形態汇言語表出を用いる必要性 があることである，逆に反応に言語を用いない残り 11 subtest ではD 群が高值を示している。すなわち言語 表出が discrepancy 出現の主要な要因であることが示 された。この結果の検証のため, 二群より各々 5 名を抽 出し WISC「一般知識」を課題反応形態を pointing に 変えて実施した。この言葉で答える必要の除去により D 群では平均 4.2 点, ND では 2.2 点の増加が認められ た。この增加值には有意差が認められ， D 群では問題 解決可能な場合でも言語表出レベルの反応がブロックさ れ結果として低值を示していることが示された。 discrepancy の要因として抽出されたこの言語表出行動の 阻害の原因に関しては今後な秥検討を要する。

<質問>東北大鳴子分院 中村 隆一: 検査項目に共 通する因子とは，心理学的な意味での factor か，それ ともテスト方法の上で output system を変えるという ことか.

<答 $>$ 岡崎 隆: 得点の増加は, 単に, 課題反応 形態を変えて言語で答える必要を除いたためと考えてい る.

\section{II-G-24，手さげ袋による compression neuropathy $の 3$ 症例}

慶応大学りハビリテーションセンター 小田 典雄 梶原 敏夫 千野 直一

日常の臨床に沶いて，様々なタイプの外力による compression neuropathy を経験するが，今回我々は， 手さげ袋による前腕部で compression neuropathy の 3 例を経験したので報告した。

症例は，障害神経，発生機序とも様々であるが，いず れも手さげ袋をかけた後に起きたものであり, 経過, 理 学的所見, 筋電図などから，手さげ袋が原因となった。 前腕部での compression neuropathy であると診断し た，一般に，重い荷物を前腕部で保持する場合，痛みや シビレなぞの知覚の警告により，外からの圧迫力による 麻痺は起きにくい。しかし, 純粋運動枝でシビレが生じ

24) Three Cases of Compression Neuropathy Cased by Hanging Bag.

N. Oda, T. Kajiwara, N. Chino: Keio Univ. School of Med. Rehabilitation Center.
ない場合や，他の様々な条件で，同じ部位に，比較的長 時間にわたり圧迫が加わる場合には，麻疩を起こすこと も考㝋られる. 更に, 圧迫が Entrapment neuropathy や循環障害の誘因となったり, 基礎に, 糖尿病やアルコ 一ル性などの全身性未梢神経障害や, 変形性脊椎症によ る radiculoneuropathy がある場合には, 圧迫により比 較的容易に麻痻が起きると考兄られる。また，それらの 因子の関与が，予後にも大きく関わってくる. 今回の症 例でも，上述の如くの原因及び予後が考光られた.

今日，日常生活に扔いて手さげ袋が多く使われるよう になっている，丈夫な袋が作られ，大きな荷重が，比較 的長時間にわたり前腕部で保持される機会が増えるに従 い, 今後, この種の麻瘦は, 更に増えることも考光られ る. 手さげ袋を持つ時の注意, 袋のひもを幅広くするな ぞの工夫により，予防することを喚起すべきであろう。

\section{II-G-25. 多発性筋炎及び 多発性硬化症にお けるリハビリテーションの 有効性 に関するー考察}

慈啓会病院内科 笠井美智子 佐藤 保則 浦沢 喜一 同リハビリテーション科 酒井喜代司 飯塚 厐

多発性筋炎のような自己免疫疾患あるいは脱䯣疾患の 代表とい光る多発性硬化症に利けるリハビリテーション の位置づけは，現在のところ治療学上明確な基準がな い. 一般的に, 前者の場合は初期の炎症症状の鎮静を待 って比較的早期にリ八訓練が開始され，赤沈や CPK 等 を指標に病変を把握しつつ行われる。 また後者では麻痺 や病性が発現している期間は可動域維持の運動を行い, 車椅子または歩行器は補助的に用いるとなっている.

今回我々の経験した多発性筋炎の症例（女性，30 歳） は発症後約 6 年を経過し, 当科入院時は両側下肢近位部 及び腰背部筋の著明な萎縮を認め歩行が高度に障害され ていた (約 $4 \mathrm{~m}$ 歩行可). 内科的治療と並行してマット 体操, 筋群毎徒手訓練 (腹筋, 背筋及び下肢諸筋群), 足関節徒手矯正，移動動作及び歩行訓練（松葉杖 $\rightarrow$ 外出 時，ロフストランド・クラッチ使用）により軽快し退院

25) A Consideration on Polymyositis and Multiple Sclerosis from a View of Rehabilitation.

M. Kasai, Y. Satoh, K. Urasawa : Jikeikai Hospital, Department of Internal Medicine. K. Sakai, A. Iizuka : Jikeikai Hospital, Department of Rehabilitation. 
した。現在日常生活をほぼ不自由なく行っている。

また多発性硬化症疑い（視力障害なし）の患者(女性， 36 歳) は昭 53 年 6 月, 両下肢の高度な知覚障害と運動 麻瘦により歩行困難な状態で入院した。入院後 2 週間目 より歩行器を用いて訓練を開始し， 2 力月後より平行棒 内起立及びバランス訓練，4 カ月後より運動浴を加光， 6 力月後に $5 \mathrm{~m}$ 独歩が 可能となった. 現在, 変化歩行 及び砂のう $(1.0 \sim 1.5 \mathrm{~kg})$ 着用負荷歩行をへて, 屋外 歩行が約 $1 \mathrm{~km}$ 可能となり, 外泊による日常生活動作 訓練続行中である.

上記 2 例はいずれも積極的なリ八訓練を行い，その効 果を期待できた症例であるが，訓練上，共通する点は， 1) 内科的治療の良好なコントロール，2）現在の症状に 関する情報を与光己管理を促進する，3）治療及びリ 八訓練に括いて患者自身の主体性を高める，4）ゴール 設定をあいまいにしない，5）こ机らを基本にすえ日常 的訓練を充分遂行しうるように，患者を中心としたチー 厶医療の体制を整備する。以上に集約されると考える.

＜質問＞慶応大学月が瀬りハビリセンター 石田 暉 : 神経疾患の運動量の増加に関しては, リハビリ医, 内科医の内で意見の相違があるが，先生の所では何をメ ルクマールK，運動量を増加しているか？

<答>笠井美智子 : 検查データ及び自覚症状（疲労度 及び意欲等）にもとづき over exercise に充分配慮して いる。

\section{II-G-26. ヘルペス神経炎 2 症例の 理学療法 を経験して}

大牟田労災病院リ八部 真島東一郎

帯状疮疹に特有な皮疹と神経痛に続いて運動麻瘏をさ たした 2 症例を報告する。

<症例 $1>76$ 歳, 男子. 最初右腰椎神経節領域, 之 りわけ大腿神経と閉鎖神経領域に水痘を伴ら皮疹と神経 痛が出現. 次いで右下肢の脱力をきたし，歩行障害とな り当院入院. 入院後も神経痛之脱力は寛解することな く，更に增悪傾向にあり，鎮痛凧の投与も一時的な寬解 しか望めず．免疫グロブリンの $2.5 \mathrm{~g}$ 隔日投与により疼 痛は著明に寛解。これ以後りハビリテーション訓練はス ムースに行えるようになり，筋力の回復をみた。この例 には温熱療法, 寒冷療法, 電気治療は無效であった。

$<$ 症例 $2>60$ 歳, 女子. 皮疹は右上腕外側, 肩胛帯

26) Physical Therapy of Herpes Zoster : Report of Two Cases.

T. Mashima: Ohmuta Labor Accident Hospital.
に認められ，知覚低下は $\mathrm{C}_{4} \sim \mathrm{D}_{1}$ の領域に認められた。 筋脱力は肘屈節群, 手関節屈節群, 母指の筋に脱力が認 められた．外来受診時すでに神経痛は寛解していた．理 学療法を行った結果，母指の運動筋に脱力を残した。

更に文献的考察を加兄てみた。

<結果>（1）帯状疮疹による四肢運動麻痺は，抒拈 む利回復の予後は良好であるが，上肢では手指の，下肢 では足関節に麻痺があると回復の予後が悪いことがあ る.（2）帯状疮疹の理学療法を行う際, 神経痛の寛解 を計らないと訓練のアプローチが難しい，理学療法のみ での神経痛の寛解は難しいと考兵る。しかし神経痛が寛 解してからの筋力増強訓練は著しい効果があると考兄 る.

＜質問＞登別厚生年金病院 大島 峻：ヘルペスに よる右坐骨神経炎が，右片麻痺患者に合併した症例があ り，某大学麻酔科で Intrathecal Phenol Bloch，そし て, 直腸膀胱障害を合併する Triplegia を作った経験 がある. 疼痛に対して理学療法で有用な緩解法があれば 御教示いただきたい。

<答>真島東一郎: 帯状疮疹の神経痛に対して, 理学 療法は効果ないと考光るが，薬物特に免疫グロブリンの 投与は効果亦ると考觉る.

＜質問＞慶応月が瀬りハビリセンター 石田＼cjkstart暉： Herpes Neuritis の痛みに関して, 理学療法は無効とい われましたが， electric stimulation をも含めてのこと でしょらか。

<答 > 真島東一郎：带状疮疹の神経痛に対して理学療 法の効果がないとするのはたしかに言い過ぎかも知れな いが， 2 例で経験した限り，理学療法は効果なかった。 これは恐らく帯状疮疹の神経痛が激しかったことに原因 があるかも知孔ない，electric stimulation に関しては 経験していない。

<質問>北海道勤医势中央病院 岡本 五十雄 : 私達 も70歳過ぎた女性で Herpes による三角筋麻疩をきた し，3力月間過ぎるが回復していない，今までの経験か ら，良い治療法があ机代教えてもらいたい。皇予後に ついても，御教示いただければ幸いです。

\section{II-G-27. 末梢神経縫合後における 知覚機能 の Central Adaptability}

\begin{tabular}{|c|c|c|c|}
\hline & 大学 & 外科 & \\
\hline 浩己 & 小山 & 格 & \\
\hline 桼 雅人 & 荼島 & 孝雄 & \\
\hline
\end{tabular}

$<$ 目的 $>$ 末梢神経縫合後の機能回復に新いて，小児で は成人に比較して非常に良好で，とくに知覚機能では， 
ほぼ正常の回復がしばしばみられる。この小児の知覚機 能回復の優秀性に関して, Central Adaptability の問題 が今日推論されており,われわれはこの点に関して, 臨 床的知覚回復と電気生理学的な面から検討を加えた。

く方法>過去 10 年間に 経験した 手関節〜前腕遠位部 での神経縫合例について，15 歳以下の小览例と 20 歳以 上の成人例に比較検討した. 臨床的知覚検查は痛覚, 触 覚と 2 点識別覚などを施行し, 回復成績を Highet 基準 に準じて判定した. 電気生理学的には知覚神経活動電位 を施行し, 経時的知覚成績と対比して検討した。

<結果> (1) 神経縫合後にいわゆる useful recovery (Highet 基準 S $2+$ 以上) 飞達するまで, 成人では 12 カ月以上を要するが，小児では 12 力月以内であった. しかし両者間の知覚伝導速度には差がみられなかった。

(2) 知覚伝導速度は小児, 成人とも神経縫合後 $2 \sim 3$ 年で plateau となり, 正常に回復することはない、し かし小児例では伝導速度が plateau となった後でも， さらに著明な知覚の回復が認められた。（3）臨床的知 覚成績の長期追跡調查に执いて, 小児例ではほとんど完 全回復を呈したが，成人例では回復状況がきわめて劣っ ていた.

〈まとめ>末梢神経縫合後の知覚機能は成人例に比較 して小児例では, 比較的早期から良好な回復が2られる が, 一方, 知覚神経活動電位をバロメーターとして評価 すると, 小児例と成人例との間に伝導速度では差異が認 められなかった。 をた伝導速度が plateau を呈した後 でも, 小児例では長期間にわたって知覚回復が著明に認 められることより, 良好な知覚獲得には Central Adaptability の関与がより示唆された.

<質問>慶応大リ八センター 木村 彰男: 末梢神経 縫合術後, 再手術を検討するに步たっての, 知覚神経伝 導速度の意義について。

<答>川鳴，順蔵：「nerve suture 後の不良回復例に 対しての reoperation について (特に小児例)」といら 質問ですが，我々は，臨床的所見を第 1 とし，それに補 助的検查方法, 知覚神経活動電位を加味して検討し, 更 に経時的にみて和ります。悍例の知覚回復良好という ことで, やみくもに, 経過観察しているのではありませ ん.

27) Central Adaptability of Sensory Function after Peripheral Nerve Sature.

J. Kawashima, H. Matsuzaki, I. Koyama, H. Masubuchi, M. Sato, T. Minejima, K. Sato: The Department of Orthopedic Surgery, Nihon University School of Medicine.

\section{II-C-28．神経・筋疾患の 手動制御に関する 研究}

\author{
国立療養所箱根病院 中島 広志 \\ 稲永 光幸 村上 慶郎 \\ 中村 正敬 久保 義信
}

トラッキング動作の解析によって, 上肢の運動機能障 害を定量的に捉えることができる. 今回, 目標入力とし てランダム波を使用した場合の各種疾患の特徴分析と, トラッキング動作の学習効果及び疲労効果について調査 したので報告する.

く方法>ブラウン管上を左右に移動する光点を, ツマ ミを指で操作することによって中心に静止させる運動を 行わせる. 零点補償型といわれる事態である. 目標入力 として，レギュラー波は $0.5 \mathrm{~Hz} \sim 4.0 \mathrm{~Hz}$ の 10 段階, ランダム波は $0.5 \mathrm{~Hz}$ カットと $1.0 \mathrm{~Hz}$ カットの 2 種を 用いた。ここに示す結果はいずれも開ループの周波数特 性である。

対象患者は進行性筋ジストロフィ一症 (PMD) 4 例, 筋強直性ジストロフィー症 (MD) 4 例, 脊髄性筋萎縮 症 (KW) 6 例, 健常者 4 例を対照とした，

<結果> (1) PMD，KW 群の軽度のものは成績良 好で, 重症になるにつれて低下する。

（2）MD，SCD 群は低周波領域から既に成績不良で ある。

（3）各疾患に批いて，学習効果が僅かに認められた.

（4）自覚的疲労状態では軽度の成績低下がみられた。

28) Studies on Mannual Control of Neuromuscular Diseases.

H. Nakazima, M. Inanaga, K. Murakami, M. Nakamura, Y. Kubo: Hakone National Hospital. 